\title{
DOI: http://dx.doi.org/10.12775/SE.2016.005
}

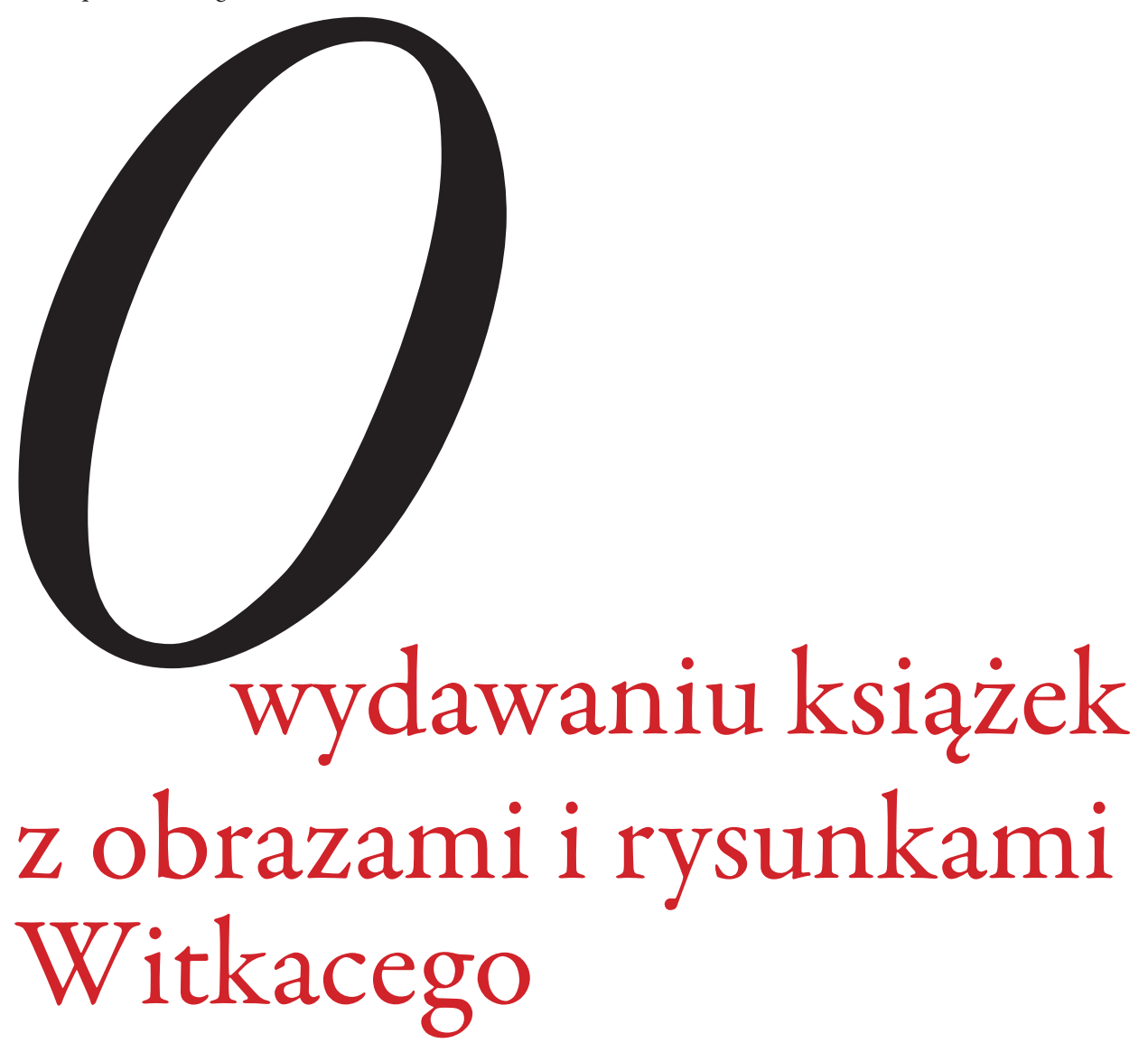

Sztuka Edycji 1/2016

ISSN 2084-7963 (print)

ISSN 2391-7903 (online)

s. $31-48$

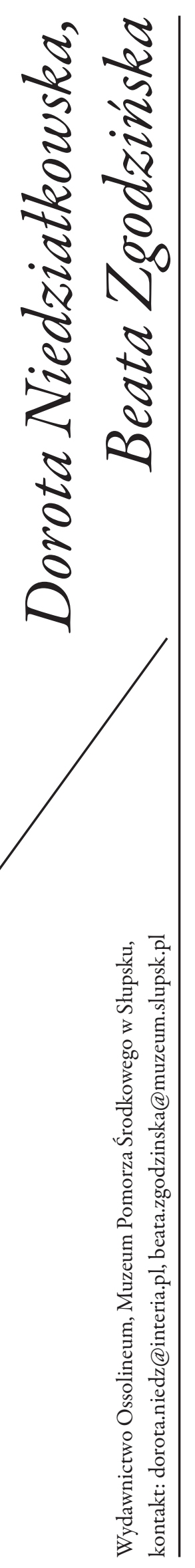

\section{Wstęp}

W tradycji i kulturze polskiej słowo odgrywa większą rolę niż obraz. Książki są w każdym domu, a dzieła sztuki - choćby tylko w postaci reprodukcji - już niekoniecznie.

Programy nauczania w szkołach różnych szczebli nie faworyzują wiedzy o sztu-

kach plastycznych, włączając zagadnienia z zakresu historii i teorii sztuki w wiedzę o kulturze, w lekcje historii czy języka polskiego. Kształcenie specjalistów z zakresu edytorstwa zazwyczaj odbywa się na filologii polskiej, co w dużym stopniu thumaczy, dlaczego późniejsi redaktorzy większy nacisk kładą na słowo, tekst niż na obraz, materiał ilustracyjny. Nic dziwnego zatem, że powstają książki historyczne bez map, książki o sztuce prawie bez ilustracji lub zupełnie ich pozbawione. Jeszcze na początku XXI wieku w spisie lektur na historii sztuki umieszczono dwutomowy podręcznik Adama Bochnaka Historia sztuki nowożytnej, który nie zawiera ani jednej ilustracji1. Odrębny i rozległy problem to ilustracje dobrane przypadkowo.

Stanisław Ignacy Witkiewicz - pisarz, dramaturg, teoretyk teatru, poeta, filozof, krytyk sztuki, estetyk, malarz, rysownik, fotograf i epistolograf - swoją wszechstronnością niewątpliwie ułatwił zadanie wydawcom. To, co napisał w jakiejkolwiek 
dziedzinie, można zilustrować czymś z bogatej twórczości plastycznej czy fotograficznej, albo przynajmniej wybrać coś na okładkę.

Znakomitym przykładem odpowiedniego doboru ilustracji do słowa pisanego jest nowa edycja Upadków Bunga, w której czytelnik znajdzie „ok. 70 rysunków, obrazów i fotografii wykonanych przez autora w okresie pisania powieści i odnoszących się do jej akcji oraz głównych postaci, które miały swoje życiowe pierwowzory"2. Pierwsza powieść Witkacego stanowi szczególny wypadek koincydencji między twórczością literacką, plastyczną i fotograficzną, kiedy pisarz, malarz, rysownik i fotograf portretuje środowisko swoich przyjaciół wszelkimi dostępnymi mu metodami artystycznymi. Od 1985 roku można było czytać Bunga z albumem Wojciecha Sztaby Zaginione obrazy i rysunki sprzed roku 1914 wedtug oryginalnych fotografii ze zbiorów Konstantego Puzyny ${ }^{3}$, zaś od 1986 roku z albumem Ewy Franczak i Stefana Okołowicza Przeciw Nicoścí. Edycja PIW-owska zbiera wszystko w jednym egzemplarzu formatu A5, co więcej - przynosi nowe, niepublikowane reprodukcje ze zbiorów Franczak i Okołowicza 5 . O jej rozlicznych zaletach można wiele pisać, oprócz przedruku wstępu Anny Micińskiej zawiera posłowie prof. Janusza Deglera, ale największym rarytasem jest Stownik postaci rozpoznanych wraz z Aneksem pióra Janusza Deglera i Stefana Okołowicza.

Z wydawaniem książek z reprodukcjami twórczości plastycznej czy fotograficznej Witkacego jest coraz lepiej. Choć i obecnie zdarzają się wypadki, że ilustracje spadają do roli ozdobników (jak w edycji poezji Witkacego z 2011 roku z kolekcji Hachette ${ }^{6}$, o czym jeszcze poniżej), a projekt graficzny nie pomaga w odczytaniu tekstu (choćby źle rozplanowane marginesy w świetnej książce zbiorowej prof. Deglera Witkacego portret wielokrotny z 2009 roku wydanej przez $\mathrm{PIW}^{7}$ ), czy też zostaje przygotowany z zupełnym lekceważeniem tego, że obrazom towarzyszy słowo pisane (poznański katalog Pamiętanie jesienia ${ }^{8}$ z 2011 roku). W tej ostatniej publikacji zastanawia, czy piksele na zdjęciu Witkacego z ponurą miną to przypadek, czy zamierzony efekt artystyczny?

Autorkom wydaje się, że warto sformułować kilka uwag na pograniczu edytorstwa, typografii i historii sztuki o wydawaniu obrazów Witkacego. Prezentowany tekst nie pretenduje do całościowego omówienia tego zagadnienia, raczej skupia się na kilku konkretnych edycjach wymagających krytyki lub pochwały i rządzi się prawem dygresji. Albumy poświęcone Witkacemu są odnotowane w najważniejszych bibliografiach, wraz z okładkami figurują wśród opracowań na stronie www.witkacologia.eu Wojciecha Sztaby.
Poniższe uwagi mogłyby nosić podtytuł: „O potrzebie, o konieczności zwracania uwagi na stronę wizualną” albo też „O konieczności świadomości wśród redaktorów tego, dla kogo i po co robią książkę". Z książek czytelnicy czerpią wiedzę (a przynajmniej powinni).

Wydawcy publikacji ilustrowanych i albumów muszą być świadomi, że dużo zależy od tego, co i w jaki sposób zostało podane do druku. Po publikacje sięgają zarówno zainteresowani, jak i badacze twórczości artysty. Początkujący historyk sztuki ma dostęp przede wszystkim do reprodukcji i na tym buduje swoją wiedzę oraz próbki analiz. Oczywiście nikt nie broni studentowi pojechać do obiektu i w muzeum, bibliotece czy teatrze skonfrontować wiedzę z dziełem sztuki. W praktyce kontakt $\mathrm{z}$ instytucją przechowującą obiekt kończy na pozyskaniu zdjęcia, do niedawna często czarno-białego - ku rozpaczy zainteresowanego. Osobna sprawa to fakt, że poza zasięgiem studenta na etapie magisterium (a także osób po prostu zainteresowanych sztuką) pozostają właściciele prywatni, mający prawo do nieujawniania innym osobom prywatnym reprodukcji posiadanych dzieł, co mogłoby się wiązać z udostępnieniem również swoich danych.

\section{Ilustracje - generalia}

Encyklopedia wiedzy o książce definiuje ilustrację jako „związane z treścią książki i czasopisma uzupełnienie w postaci oryginalnego lub za pomocą właściwej techniki zreprodukowanego rysunku, ryciny, obrazu lub zdjęcia fotograficznego"10. W szerszym znaczeniu to nawet ornament zdobiący kartę tekstu, treścią odpowiadający charakterowi książki.

Określenie roli ilustracji wobec tekstu to jeden z pierwszych kroków redaktora, redaktora technicznego czy grafika w trakcie projektowania kształtu edytorskiego publikacji. Redaktorzy z reguły nie lubią takich książek, ale lubią je czytelnicy. Książki „z obrazkami” wymagają więcej zaangażowania, rozsądnego projektu typograficznego uwzględniającego ilustracje, a gdy te mają być w tekst włamane - makiety; weryfikacji spisu ilustracji, przygotowania na jego podstawie skróconych podpisów do ilustracji (o ile nie zrobił tego autor), a następnie długiej pracy ze składaczem nad właściwą realizacją zamierzenia... Zresztą każdy, kto z czytelnika stał się współtwórcą procesu wydawniczego i doprowadził do wydania przynajmniej jednej książki niezawierającej samego tekstu, nieco inaczej i z większym szacunkiem patrzy na tę pracę.

Filip Trzaska w Poradniku redaktora wyróżnia trzy podstawowe sytuacje ${ }^{11}$. Ilustracje mogą być w książce: 1) integralną 
częścią tekstu, konieczną do rozumienia toku wykładu;

2) elementem uzupełniającym treść, którego istnienie nie jest konieczne do rozumienia i nie przesądza o przydatności i wartości dzieła oraz 3) przerywnikiem urozmaicającym monotonię graficzną długich partii tekstu. W pierwszym wypadku powinny być włamane $\mathrm{w}$ tekst $\mathrm{w}$ miejscu bezpośrednio związanym z poruszanym zagadnieniem, a jeżeli technicznie nie jest to możliwe, to nieco dalej na tej samej kolumnie lub na kolumnie obok (tzw. rozwarcie) w zasięgu wzroku czytającego. Drugi rodzaj ilustracji, luźniej związany z tekstem, można umieszczać w oddaleniu od treści, jako wkładki. Wkładki (lub, jak wolą autorzy Typografii ksiażki ${ }^{12}$, składki ilustracyjne) dawniej różnicowano pod względem surowców (papier zwykły, dla kolorowych ilustracji najczęściej kredowy), warunkowała to technika druku. Pierwsze dwa rodzaje ilustracji jako powiązane z tekstem są, co oczywiste, numerowane, opatrzone podpisami i szczegółowo pod względem danych katalogowych opisane w spisie. Trzeci rodzaj to najczęściej ornamenty, różnego rodzaju bordiury, winiety, przerywniki, finaliki, które nie wymagają takiej edytorskiej akrybii. Jako że tylko zdobią, na ich umiejscowienie w książce mają wplyw smak i gust grafika czy redaktora technicznego, nie zaś racje merytoryczne (ale w praktyce też objętość tekstu i po prostu projekt typograficzny).

W powyższych wypadkach ilustracja była poddana tekstowi. Ryciny, rysunki i reprodukcje zaopatrzone w krótkie objaśnienia mogą jednak funkcjonować samodzielnie w atlasach, albumach i zbiorach rycin. Jeżeli ich geneza nie wiąże się z koniecznością wspomagania wspólistniejącego z nimi tekstu, wówczas nie powinno się, zdaniem Janiny Wiercińskiej, nazywać ich ilustracjami ${ }^{13}$.

Współczesny album wywodzi się od piętnastowiecznych publikacji szerzących wiedzę o świecie i człowieku za pomocą obrazków uzupełnionych krótką legendą (serie portretów, widoków miast, zwierząt, roślin, później także dzieł sztuki, zabytków architektury, rzeźby czy malarstwa). Nazwę przejęto w XIX wieku z albumów pamiątek i zeszytów z litografiami wydawanych przez artystów francuskich ${ }^{14}$. Wiercińska wylicza dziewiętnastowieczne przykłady takich edycji, zawierających reprodukcje eksponatów wielkich wystaw, zabytków sztuki, sztuki regionu, dzieł jednego lub wielu artystów ${ }^{15}$. Plansze takiego wydawnictwa były przeznaczone dla widza, nie dla czytelnika.

W albumie materiał ilustracyjny odgrywa podstawową rolę i tworzy zasadniczy trzon książki, podporządkowując sobie tekst bądź ograniczając go tylko do funkcji podpisów wyjaśniających lub komentujących poszczególne plansze. Jeżeli jednak chodzi o przygotowanie takiej książki, znowu warto przywołać Trzaskę. Przestrzega on, by reprodukcje dzieł sztuki drukować nieodzownie z passe-partout, ,aby pokazać obraz w całości bez zniekształceń wynikłych na skutek obcięcia krawędzi”" ${ }^{16}$.

W praktyce realizacja tego postulatu nie jest taka prosta. Jednym z chyba nierozwiązywalnych problemów, zwłaszcza przy reprodukowaniu pasteli czy węgli Witkacego, jest kadrowanie. Sporo z tych dzieł, wykonanych na papierze, jest oprawionych w passe-partout (często grube), szkło i ramę. Okienko wycięte w przedniej części passe-partout zakrywa papier przynajmniej po pięć milimetrów przy każdej krawędzi ${ }^{17}$, zatem niekiedy skraj kompozycji jest schowany. Witkacy dość szczelnie wykorzystywał papierowe podobrazie, dlatego przy oprawianiu jego niektórych prac pewne fragmenty napisów już są schowane pod passe-partout lub pod ramą. Gdy takie obiekty oświetla się do sfotografowania, to nieuchronnie pojawia się cień, niekiedy dość szeroki i głęboki (zob. il. 1 i il. 2).

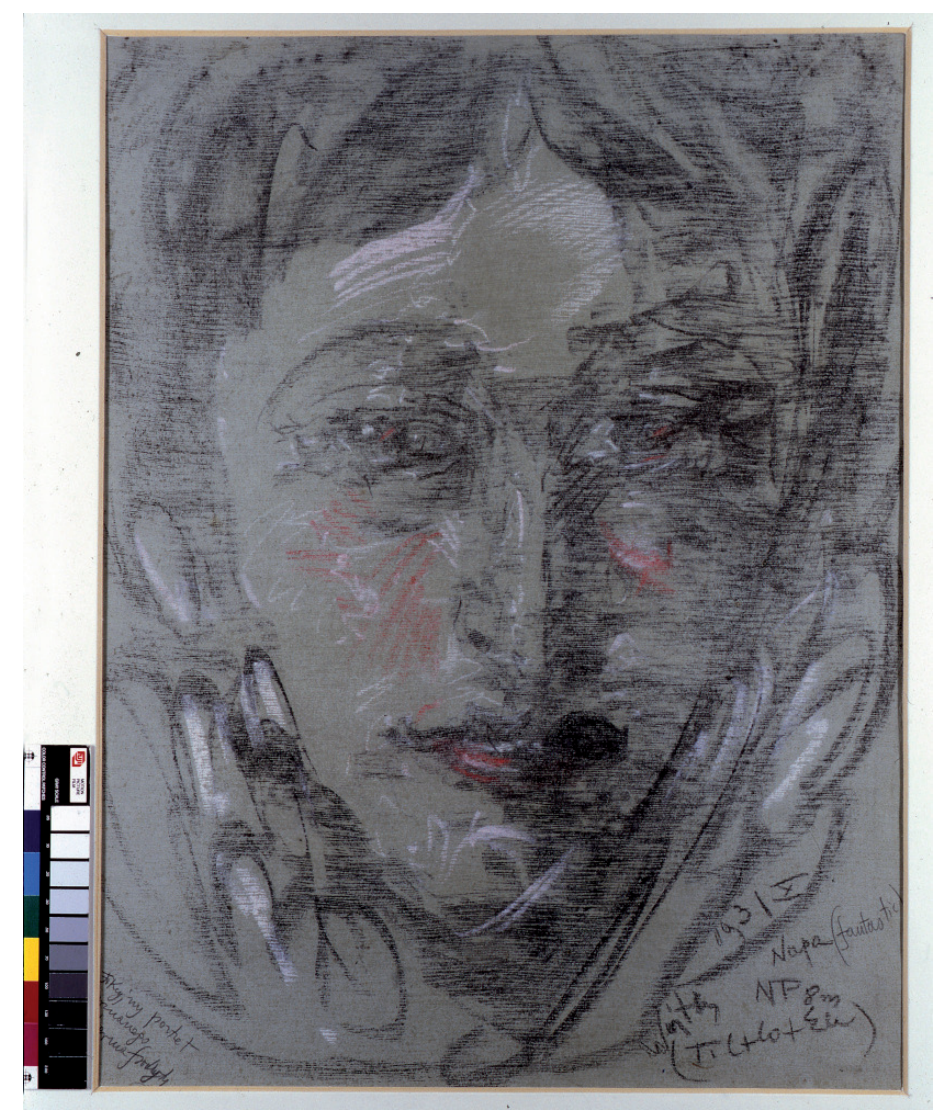

Il. 1. Portret fikcyjny, 1931, pastel, Muzeum Pomorza Środkowego, nr inw. MPŚ-M/105 


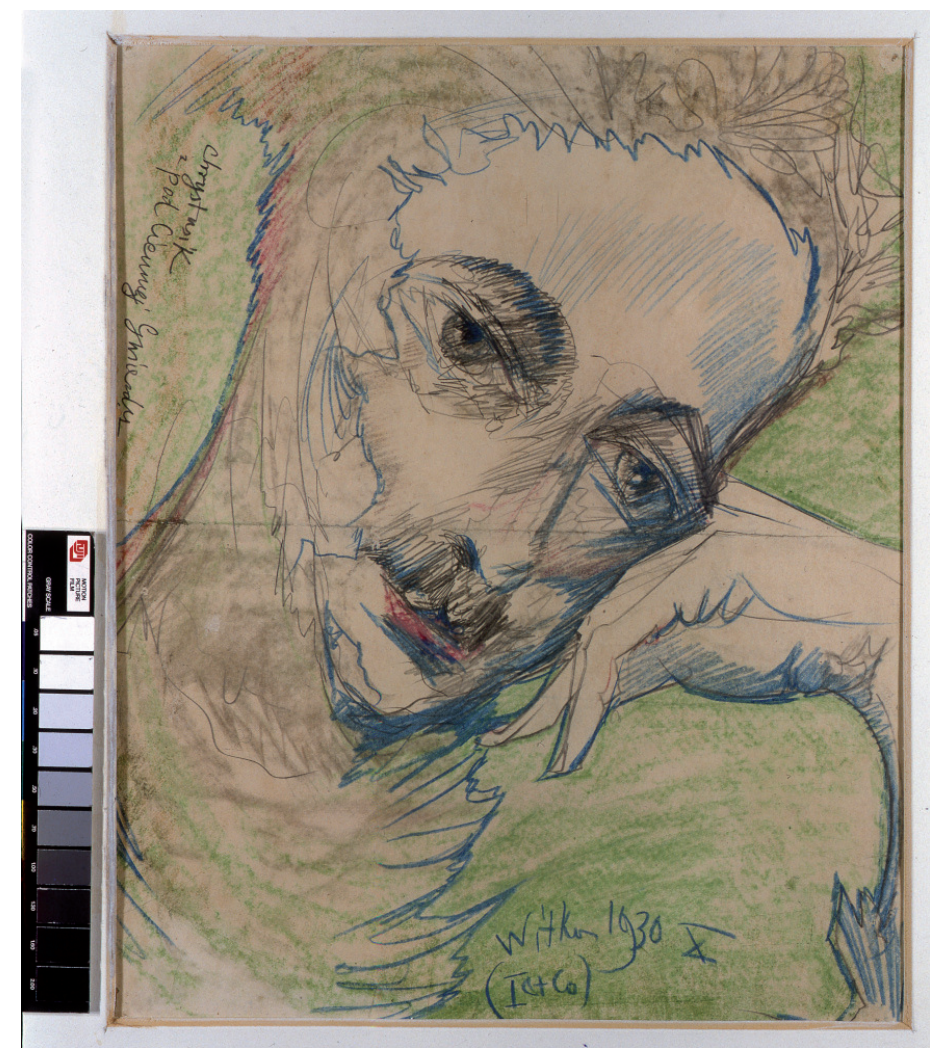

Il. 2. Portret Stanistawa Totwena, 1930, pastel, Muzeum Pomorza Środkowego, nr inw. MPŚ-M/100

Graficy różnie radzą sobie z tym problemem - najczęściej po prostu obcinają owe ciemniejsze paski, w efekcie czego zdarza się, że zostaje ucięta też część sygnatury. Dochodzi zatem do dwukrotnego „uszczuplenia” autorskich napisów lub fragmentów kompozycji, często ze zmianą jej proporcji. W skrajnym przypadku obcinanie powoduje, że nie wiadomo, czy mamy do czynienia jeszcze z wykadrowanym obrazem, czy może już z reprodukcją jego fragmentu. Rzadko pozostawiony jest ciemny pasek cienia ramy i fragment samej ramy. Może nie jest to złe rozwiązanie, o czym świadczy reprodukcja kompozycji astronomicznej Antares w Skorpionie zamieszczona w Marginaliach filozoficznych ${ }^{18}$ (zob. il. 3).

Inną metodą jest retuszowanie - sposób tyleż skuteczny, co pracochłonny. $Z$ uwagi na delikatną technikę, jaką jest pastel, jest zdecydowanie niewskazane fotografowanie go bez passe-partout, które pełni funkcję ochronną w stosunku do dzieła.

Obrazy olejne zazwyczaj są fotografowane w ramach (zob. il. 4). Incydentalnie są z nich wyjmowane - tak było, gdy w 1995 roku robiono zdjęcia słupskiej kolekcji Witkacego, w związku z przygotowaniami do wydania albumowego katalogu kolekcji. Zdecydowano się na ten zabieg, gdyż sygnatura Pejzażu wtoskiego jest na krawędzi płótna, zatem po oprawieniu obrazu w ramę pozostaje częściowo niewidoczna (zob. il. 5).

Sztuka Edycji 1/2016
W książce obraz został wykadrowany (i zreprodukowany częściowo na spad), zatem części sygnatury nadal nie widać. Może warto byłoby zatem zastanowić się nad reprodukowaniem całych sfotografowanych dzieł - oczywiście, trochę ucierpiałaby strona wizualna książki, ale kosztem jej walorów poznawczych. Herkules i lew pokazany w książce Ireny Jakimowicz Witkacy malarz w całej okazałości, bez kadrowania, czyli ze wszystkimi ubytkami i naddarciami przy krawędziach, nic nie stracił ze swojej atrakcyjności ${ }^{19}$.

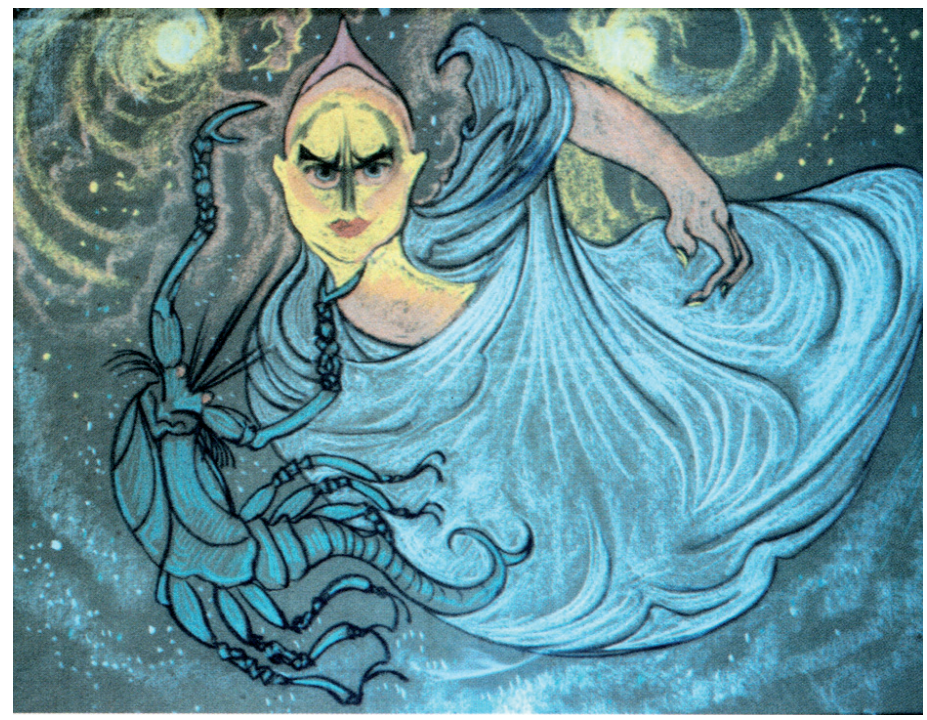

Il. 3. Antares w Skorpionie (Marginalia filozoficzne, red. P. Polit, Warszawa 2004, s. 60)

Należy mieć na względzie także i to, że rzadko który obraz czy rysunek jest idealnym prostokątem, zatem równe, prostokątne reprodukcje w książkach to rodzaj swoistego przekłamania. Reprodukcje są doprowadzone do stanu „idealnego” za cenę utraty wierności.

W tekstach poświęconych pastelom często można spotkać określenia „pędzlem”, co jest oczywistym poważnym błędem. Podobnego kalibru pomyłką jest pisanie o podobraziu portretów pastelowych Witkacego: „płótno”. Pomyłki takie zdarzają się nawet historykom sztuki! Pastel jest techniką malarską pośrednią między malarstwem a rysunkiem - rysuje się pałeczkami (kredkami) uformowanymi z pigmentów, kredy, gipsu i niewielkiej ilości spoiwa (głównie gumy tragantowej) ${ }^{20}$. Stosowane są dwa rodzaje kredek pastelowych: tłuste i suche. Witkacy posługiwał się suchymi pastelami, których nie utrwalał (ewentualne utrwalanie fiksatywą zmienia intensywność barw). 


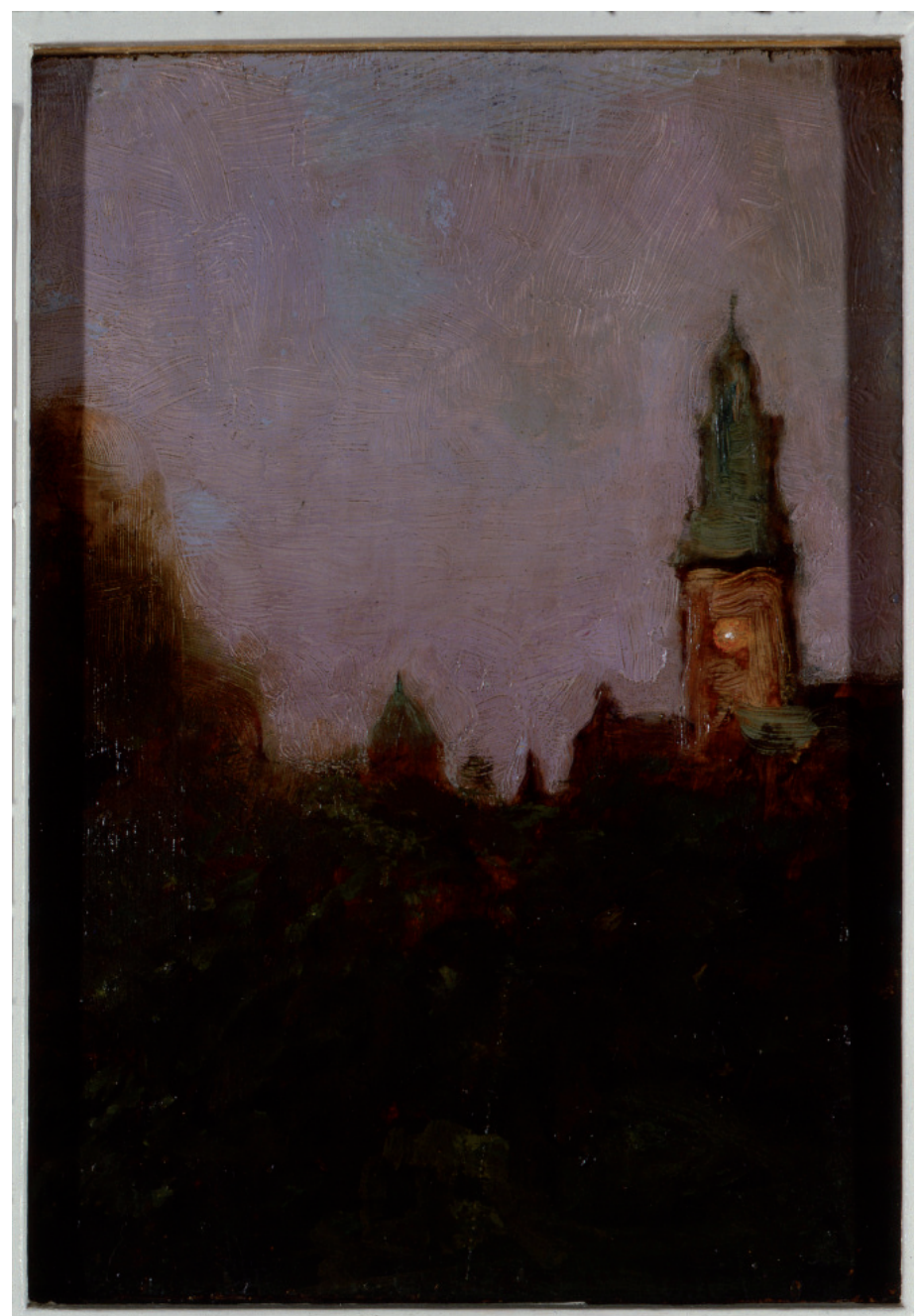

Il. 4. Widok Wawelu (odwrocie Autoportretu z odbicia w szybie), 1906, olej, Muzeum Pomorza Środkowego, nr inw. MPŚ-M/135

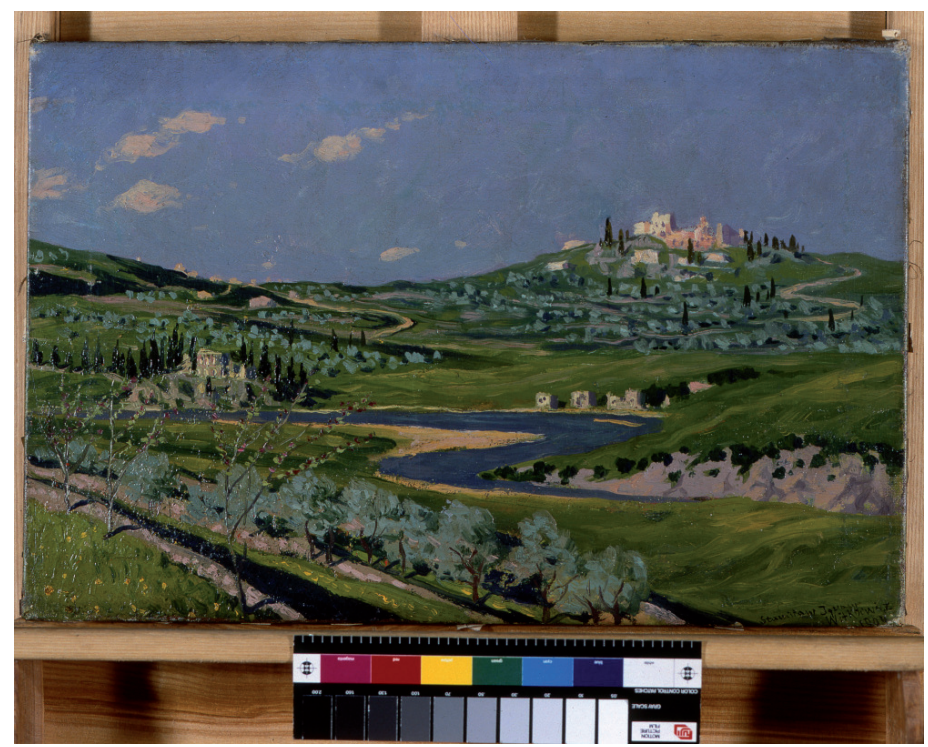

Il. 5. Pejzaż wtoski, 1904, olej, Muzeum Pomorza Środkowego, nr inw. MPŚ-M/1223

\section{Albumy i nie tylko}

„Znaczenie materiału ilustracyjnego jest największe w przypadku albumów i reprodukcji dzieł sztuki, dalej w książce dziecięcej - obrazkowej oraz w dziełach specjalistycznych: w literaturze technicznej i naukowej"21 - notuje Filip Trzaska. Skupmy się na pierwszych dwóch wypadkach.

Pierwsze albumy poświęcone twórczości Stanisława Ignacego Witkiewicza to schyłek lat siedemdziesiątych. W 1977 roku Anna Micińska i Urszula Kenar podały do druku znakomitą książkę Stanistawa Ignacego Witkiewicza wiersze i rysunk $i^{22}$. Zalety tego przynoszącego nieznany materiał ilustracyjny i tekstowy wydawnictwa wydobywa jego współczesny, ale niezbyt udolny naśladowca: wspomniana już Antologia ${ }^{23}$ poezji Witkiewicza z 2011 roku.

O wywołującym komiczny efekt zderzeniu zawartości z szatą graficzną kieleckiej Antologii wspominał Marek Średniawa: „W oprawie z czerwonego skóropodobnego tworzywa ze złotymi tłoczeniami i stylizowanymi kwiatami maku, sugerującej subtelną lirykę milosną, czytelnik znajdzie wybuchową literacką kontrabandę, którą otwiera wiersz Do przyjaciót gówniarzy [...]"24. Zaznaczmy, zaplanowana na dziewięćdziesiąt tomów popularna seria Hachette prezentuje największe dzieła poezji polskiej w typowym dla tomików kształcie, w formacie większym niż kieszonkowy $(115 \times 185 \mathrm{~mm}) \mathrm{i}$,w szlachetnej oprawie"25 (zob. il. 6). Stylizowane kwiatki groszku pachnącego w odcieniach fioletu zdobily poetyckie dzieło Jana Andrzeja Morsztyna, zaś swojskie jaskry - Jana Czeczota. Okładkę tomiku Brunona Jasieńskiego dekorowały baldaszki dzikiego kopru na błękitnym tle. Wydaje się, że jedynie szaro-czarna okładka tomiku Marcina Świetlickiego była nieśmiałym sygnałem, że pastele i wzory floralne nie do wszystkiego pasują. Próba wyłamania się ze skądinąd morderczego „prawa serii” pozostała odosobniona ${ }^{26}$.

Problem jednak leży gdzie indziej. Poprzedni akapit rozpoczynał się od przywołania Stanistawa Ignacego Witkiewicza wierszy i rysunków. Wprawdzie anonimowy redaktor wstępu do Antologii z 2011 roku oddał należną chwałę Micińskiej i Kenar („My w naszej publikacji podążymy śladem przetartym tamtą nowatorską książką") ${ }^{27}$, ale przedrukował teksty i zawłaszczył sobie pomysł na uporządkowanie materiału, prokurując jego gorszą wersję. Niemal wszystkie wiersze podano w porządku edycji z 1977 roku. Informacji o tym, co jest podstawą przedruku wierszy i ilustracji, nie znajdziemy ${ }^{28}$. Za to spore passusy Postowia Anny Micińskiej anonimowy redaktor umieszcza we Wstępie (zachowane oznaczenia cytatu). Do jego pisania 
wykorzystał też album Ireny Jakimowicz Witkacy - malarz z 1985 roku. Drugi tytuł posłużył także jako źródło do reprodukowania ilustracji.

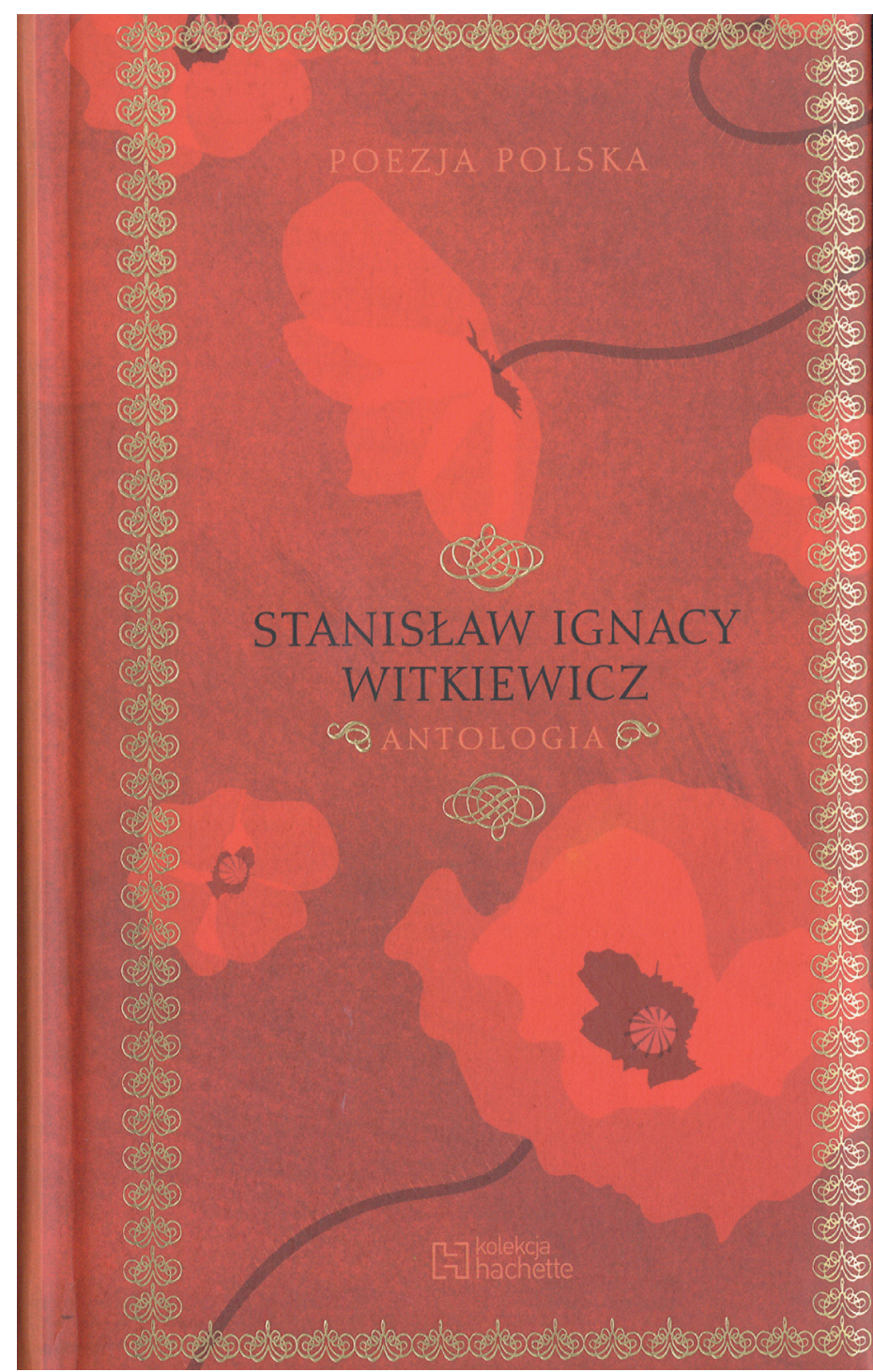

Il. 6. Pierwsza strona okładki Antologii S. I. Witkiewicza (Kielce 2011)

Micińska i Kenar w nocie objaśniły układ książki, wytłumaczyły się, że ich zamierzeniem nie była ani edycja krytyczna poezji, ani muzealny katalog rysunków Witkacego. Dlatego nie ma danych katalogowych materiału ilustracyjnego, a są fotograficzne miny, złote myśli czy fragmenty pism krytycznych skonfrontowane z przejawami praktyki poetyckiej. Układ materiału w Antologii nie był raczej przedmiotem głębszego namysłu. Vive la gvazdére, a następnie Do przyjaciót lekarzy (stanowiący w Wierszach i rysunkach kompozycyjną klamrę z Do przyjaciót gówniarzy, choć zakończeniem jest diagnoza na temat odrodzenia Czystej Formy Witkiewicza z Teorii Czystej Formy w poezji $)^{29}$ już się nie zmieściły albo też uznano, że czymś książki muszą się różnić. Zapewne dlatego zrezygnowano z oznaczenia cykli poetyckich (wiersze, poematy i „śpiewki” bohaterów utworów Witkacego, poranne piosenki kąpielowe Stasia i wiersze do Tymbciów).

Micińska i Kenar pozwoliły czytelnikom samodzielnie odpowiedzieć na pytanie, czy wiersze Witkacego są poezją. Urszula Kenar, bo jej zawdzięczamy projekt okładki, obwoluty oraz opracowanie graficzne, zagrała w tym celu konwencją edytorską książki. Wewnętrzna strona wyklejki i strona przedtytułowa czwórki wydawniczej zawierają niejako dialogujące ze sobą i z czytelnikiem zdjęcia Witkiewicza oraz jego uwagi krytyczne na temat jakości swych „wyrobów”, niechęci do formy, ale i pochwały „ładnej myśli” wiersza (te strony w tzw. rozwarciu zob. il. 7).

W edycji z 2011 roku tej decyzji edytorskiej nie zrozumiano, wymienione cytaty figurują jako pełnoprawne wiersze, każdy na stronie nieparzystej, ujęte w spisie treści. Zagadnienie bycia przez Witkacego poetą skomentowano zaś jednozdaniowo we wstępie. Ponadto pominięto lub skrócono passusy autokomentarza teoretycznego. Z obszernego materiału ilustracyjnego obejmującego rysunki, pastele, fotografie i rękopisy wybrano tyle, by każdemu z siedemdziesięciu pięciu tekstów na stronie nieparzystej, „ważniejszej”, odpowiadała jakaś ilustracja na stronie parzystej. Ilustracje skadrowano do ustandaryzowanych wymiarów kolumny tekstu. Zbliżony do kwadratu format książki z 1977 roku oraz nowoczesna koncepcja wydawnicza pozwalały na rozmieszczenie tekstu i ilustracji w sposób znacznie bardziej różnorodny. Witkacy w edycji kieleckiej uklasycznił się $i$,ugrzecznił” pod względem projektu typograficznego. Może z wyjątkiem czerwonego druku, na szczęście w dużo spokojniejszym odcieniu niż żywa czerwień okładki wybijającej się na tle pastelowej serii.

Jeżeli chodzi o ilustracje, minimalny trud odróżnienia od siebie książek wydawca Antologii jednak podjął. W większości wypadków zmieniono zestaw „tekst + ilustracja”. Zrobiono to z różną trafnością, wykorzystując najczęściej dosłowne skojarzenie obrazowe (z tego korzystały też, ale z racji wiedzy i znajomości tytułów rysunków znacznie trafniej autorki edycji z 1977 roku). Do wiersza rozpoczynającego się od incipitu [Więc tylko trochę mniej oporu], w którym pada fraza „ach, o kotki me”, dopasowano w Antologii fragment rysunku Doktadne mierzenie ohydy życia (zaczerpniętego z albumu Jakimowicz z 1985 roku) ukazujący dwa koty z postacią mierniczego, zaś do czterowiersza rodzica, zrozpaczonego, że jego syn jest pyknikiem, dobrano kadr z Podwieczorku astralnego, na którym stworek o gruszkowatym brzuszku (wedle autora „pani Eckerton”) widnieje obok stworka o podługowatym 


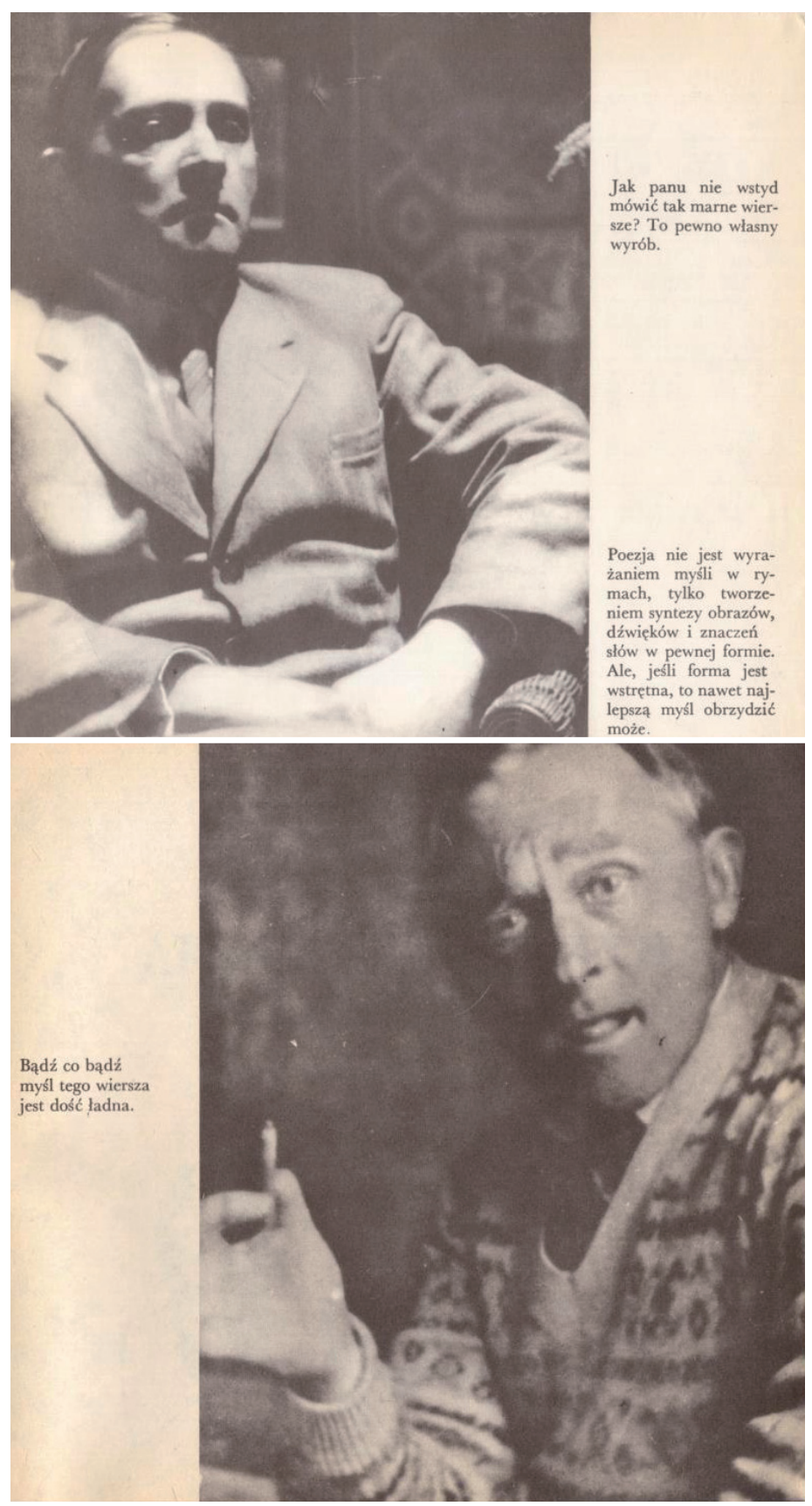

Il. 7. Dwie strony między wyklejką a czwórką w książce Stanistawa Ignacego Witkiewicza wiersze i rysunki (wybrały i do druku podały A. Micińska i U. Kenar, Kraków 1977, s. 0-1)

ciele (podpisanego „Bohdan”). Przy rymowance „o obłapce” reprodukowano fragment Kompozycji symbolicznej z 1914 roku (także za Jakimowicz), na rysunku węglem demoniczna postać męska otacza ramieniem leżącą postać kobiecą. Na potrzeby serii dystychów „a gdy ją ujrzał tak w refleksach całą” nie wahano się wydrukować obróconej o 90 stopni, pozbawionej sygnatury i napisu zaczerpniętej z albumu Jakimowicz Joasi z żórawiem [!] (zob. il. 8). Kompozycja ta to leżący, a nie stojący prostokąt ${ }^{30}$.
Oczywiście te działania powodują powstanie nowych zestawów słowno-obrazowych, wywołujących nowe skojarzenia i nowe możliwości interpretacji... Można jednak mieć nadzieję, że amatorzy poezji, kiedy już zetkną się z Witkacym i znajdą go interesującym, sięgną do edycji pozwalającej zobaczyć więcej niż tylko miniaturowe „bordo” Witkace (a z racji przedruku $\mathrm{z}$ lat siedemdziesiątych zamazane i nie do końca satysfakcjonujące pod względem jakości).

Anna Micińska i Urszula Kenar dały materiałowi ilustracyjnemu i tekstom równe prawa. Całość prezentuje zresztą wiele odważnych i odpowiadających duchowi nietypowego materiału rozwiązań typograficznych: jak choćby wyklejki zapełnione autoportretami, nowatorsko potraktowana czwórka tytułowa (stronę przytytułową wypełnia szkic z wierszem „Nie szukaj już niczego - / Bo wistość tych rzeczy / Jest nie z świata tego", zaś cytat „wistość tych rzeczy jest nie z świata tego" figuruje na stronie tytułowej większym stopniem pisma $\left.{ }^{31}\right)$, czarne strony $\mathrm{z}$ tekstem w kontrze, druk do góry nogami, rysunki często reprodukowane „na spad”, kadry zbliżeń pozwalające przeczytać sygnatury rysunków ${ }^{32}$... Na obwolutę białego płótna wybrano bardzo dekoracyjny, kontrastujący pod względem zestawień czerni i bieli, ale i nieco prowokacyjny rysunek przedstawiający profesora Fuchsthala wywotującego wyobraźniowo diabetka na stole jadalnym po kolacji opatrzony etykietką „Witkacy” (zob. il. 9). Prowokacyjny, bo w pewnym sensie stanowiący kwintesencję tego, z czym kojarzy się autor: na stole przy czyniącym sztuki na jednej ręce diabełku leżą wszak kuleczki i pudełko podpisane „Peyotl”. Jeżeli chodzi o ocenę krytyczną Wierszy i rysunków, należy ubolewać jedynie nad brakiem koloru oraz tym, że książkę wydrukowano na zbyt cienkim papierze offsetowym (o gramaturze 90, III klasa ${ }^{33}$ ).

Bardziej klasyczną formę przybrała książka z ilustracjami Witkacego pióra Ireny Jakimowicz z 1978 roku. Witkacego. Chwistka. Strzemińskiego. Myśli i obrazy ${ }^{34}$ wydano w formacie B5, z czterdziestoma ilustracjami autora Pożegnania jesieni (trzydzieści dwie czarno-białe oraz dziewięć w kolorze na papierze kredowym). Każda ilustracja jest umieszczona na oddzielnej stronie, w kompozycji sąsiednich stron najczęściej wybierane są układy po przekątnej.

Album z prawdziwego zdarzenia (choć wedle typologii Wiercińskiej byłaby to książka z ilustracjami) Irena Jakimowicz opracowała w 1985 roku. Witkacy - malarz ${ }^{35}$ składa się ze złożonej w dwie kolumny partii tekstu (głównie przedruki świetnych artykułów autorki, ss. 88 wraz z katalogiem) oraz barwnej części ilustracyjnej (ss. 80, papier kredowy). Książka w przyciętym formacie $\mathrm{B} 4$ to bodaj pierwsze $\mathrm{z}$ wydawnictw prezentujące aż dwieście czterdzieści reprodukcji z malarskiego, 


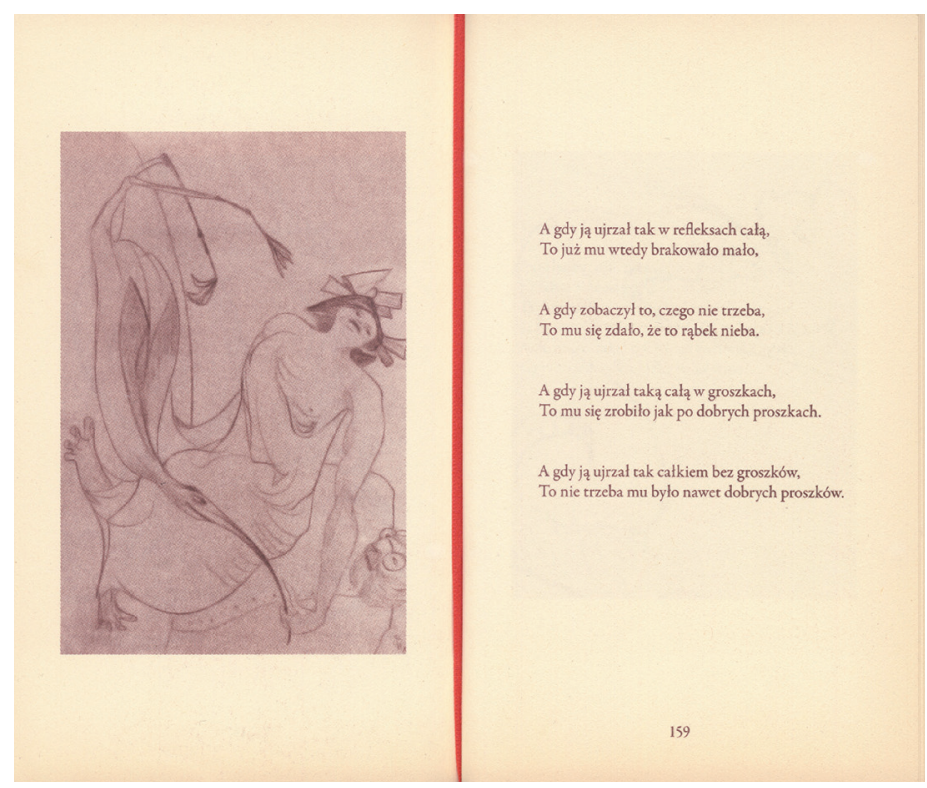

Il. 8. Rysunek Joasia z żórawiem [!] oraz strona z wierszem [A gdy ja ujrzat tak w refleksach cata] z Antologii S. I. Witkiewicza (Kielce 2011, s. 158-159)

rysunkowego i fotograficznego oeuvre'u artysty. Wliczam w to już część z tekstami zawierającą materiał czarno-biały: fotografie, rysunki, afisze i plakaty. Fotografie podano z czarnym passe-partout lub na całej czarnej karcie - rozwiązanie to sprawdzi się świetnie w albumie fotograficznym Przeciw Nicości.

Zasadniczo chronologicznego porządku materiału ilustracyjnego, pozwalającego na rekonstrukcje faz w twórczości pla-

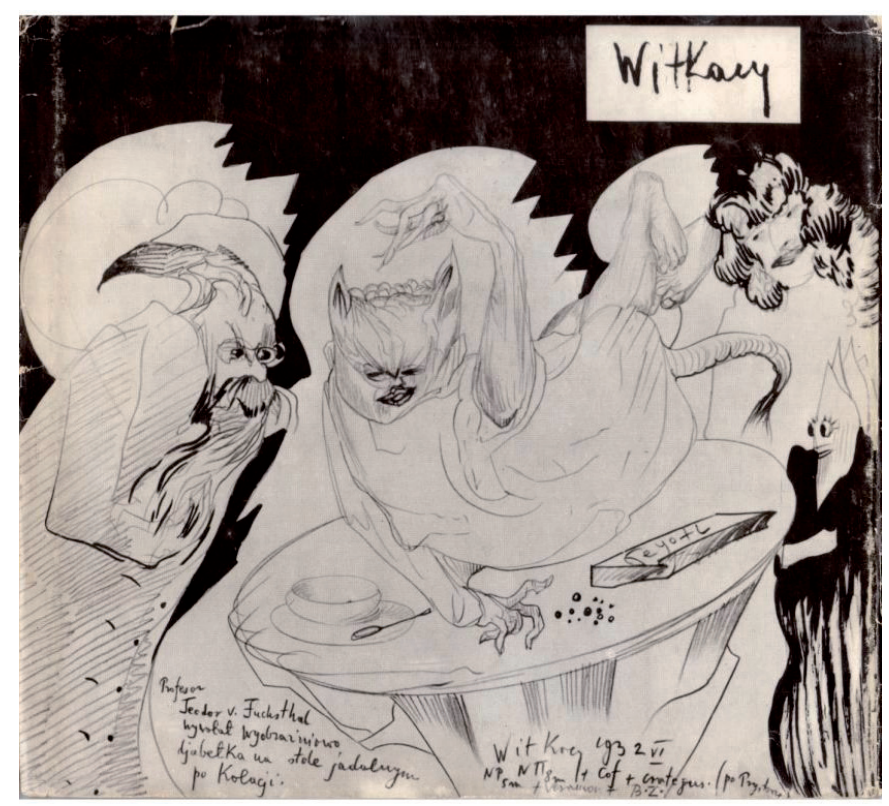

Il. 9. Pierwsza strona obwoluty Stanistawa Ignacego Witkiewicza wierszy i rysunków (wybrały i do druku podały A. Micińska i U. Kenar, Kraków 1977) stycznej Witkiewicza, nie burzą rysunki rozmieszczone głównie tam, gdzie pozwoliło na to miejsce (nad lub pod obrazami w kształcie leżącego prostokąta). Sporo rysunków podano w naturalnej kolorystyce - jak choćby Choromańskiego rzygajacego na mnie. Za szczególnie cenne uważamy ukazywanie w kilku wypadkach niewyrównanych krawędzi papieru w rysunkach czy pastelach (np. Lew i Herkules, il. 27, o czym już wspominałyśmy powyżej), świadczące o rzeczywistym stanie zachowania obiektów. Niestety w wypadku pasteli z racji oprawy linie cięcia przebiegają po sygnaturach. Większość dzieł Firmy Portretowej to stojące prostokąty, zajmujące w edycji całe stronice: od wersji z passe-partout, przez częściowy i całościowy „spad”. W wypadku portretów jednej osoby powstaje galeria - dzięki takiemu zabiegowi ciekawie prezentuje się przejście od realistycznych do czysto formistycznych portretów Teofila Trzcińskiego. Często o sąsiedztwie decyduje jakaś cecha formalna, np. podwójność portretów czy wężowatość. Witkacy - malarz nie unika zabawnych dodatkowych sensów, jakie wynikają z zestawienia dialogujących ze sobą obrazów. Chodzi o Zdzisława Skibińskiego na ptasich łapkach, którego zwrot głowy i linia wzroku wypadają akurat symetrycznie i na tej samej wysokości co u Janusza Kotarbińskiego ukazanego jako głowa polatująca nad górami (w albumie il. 146 i 147, w prezentowanym artykule zob. il. 10). Uśmiech Skibińskiego, jakim obdarza Kotarbińskiego, nie przeszkadza w niczym czytelnikowi.

Typografia Witkacego - malarza prezentuje się bez zarzutu (może jedynie współcześnie nieco rażą nieumieszczone we frakcji górnej ułamki, zaburzające jednostajność interlinii w katalogu).

Kolejnym wydawnictwem, w którym zreprodukowano bardzo dużo, bo aż sto dziewięćdziesiąt trzy prace Witkacego, był katalog słupskiej kolekcji dzieł Stanistaw Ignacy Witkiewicz. Witkacy 1885-193936. Autorką opracowania jest Anna Krzyżanowska-Hajdukiewicz - ówczesny kustosz kolekcji, autorka scenariusza pierwszej wystawy stałej w słupskim muzeum, otwartej w maju 1982 roku. Katalog ukazał się jesienią 1987 roku, obejmuje nabytki do końca 1983 roku. Były to czasy, w których cykl wydawniczy trwał długo, z dzisiejszej perspektywy wręcz bardzo długo - i to nie tylko dlatego, że cały proces przygotowania książki odbywał się metodą tradycyjną: do drukarni wysyłano maszynopis, a tekst składany był przez zecera. Gdy materiał był już gotowy, dość długo trwało znalezienie przez muzeum wydawnictwa, które byłoby skłonne rzecz całą przygotować do druku i wydrukować - ostatecznie zadania tego podjął się Zakład Wydawnictw „Sztuka Polska”. Warto zwrócić uwagę na ówczesne nakłady: katalogu zbiorów regionalnego muzeum wielodziałowego (bo takim przecież jest Muzeum 


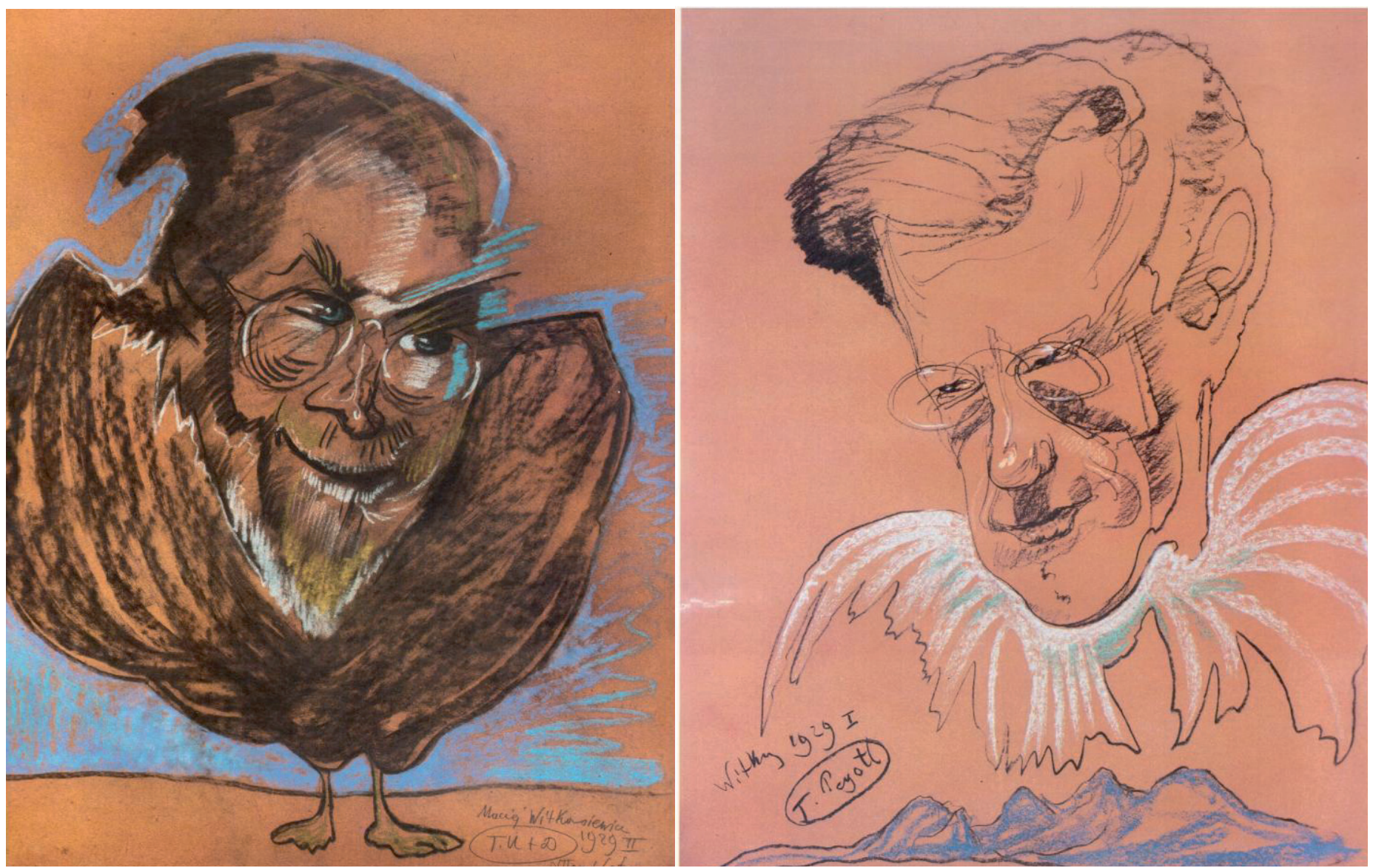

Il. 10. Portrety Zdzisława Skibińskiego oraz Janusza Kotarbińskiego (I. Jakimowicz, Witkacy - malarz, Warszawa 1985, il. 146 i 147, strony nlb.)

Pomorza Środkowego w Słupsku) wydrukowano aż dziesięć tysięcy egzemplarzy; ostatnie sprzedano w listopadzie 2010 roku. Informacje o nakładzie, liczbie arkuszy wydawniczych i drukarskich, rodzaju papieru znalazły się w stopce redakcyjnej - niestety, współcześnie niemal zapomnianym elemencie książki.

Wstęp i notę biograficzną przetłumaczono na angielski i rosyjski, natomiast tylko po polsku zostały opublikowane pozostałe części: fragmenty tekstów Witkacego, regulamin Firmy Portretowej, fragmenty listów do żony oraz właściwy katalog (spis dzieł, łącznie z bibliografią i udziałem w wystawach, wyjaśnienie skrótów, spis wystaw). Dzieła Witkacego zostały podzielone na cztery grupy w zależności od techniki wykonania, w obrębie każdej z grup układ prac jest chronologiczny. Układ ilustracji powtarza układ katalogu. Plusem takiego rozwiązania jest opatrzenie każdej pracy tylko jednym numerem pozycji katalogowej, będącym zarazem numerem ilustracji. Brak podwójnej numeracji niewątpliwie ułatwia korzystanie z katalogu, zmniejsza ryzyko pomyłki np. przy cytowaniu. Minusem jest brak możliwości dopracowania poszczególnych stron i rozkładówek od strony plastycznej oraz niemożliwość ułożenia obok siebie reprodukcji dzieł podobnych (bądź różnych).
Katalog ma format zbliżony do kwadratu $(220 \times 230 \mathrm{~mm})$. Tekst został złożony w dwóch kolumnach, reprodukcje - od jednej do sześciu na stronie, a na rozkładówkach od dwóch $(1+1)$ do dwunastu $(6+6)$, z ośmioma wariantami pośred$\operatorname{nimi}(2+1,6+1,1+2,2+2,5+1,3+1,6+5,1+5)$. Podpisy są ograniczone są do minimum i obejmują numer katalogowy, tytuł oraz rok; niestety, brakuje wymiarów, zresztą bardzo często pomijanych przez autorów, redaktorów i wydawców. Umieszczenie obok siebie reprodukcji różnych rozmiarów wprowadza czytelnika w błąd, gdyż nieświadomie odbiera on prace jako dzieła o różnej wielkości, a portrety pastelowe Witkacego mają bardzo zbliżone wymiary.

W pierwszym słupskim katalogu kolekcji niemal wszystkie reprodukcje są kolorowe; szkoda, że czternaście rysunków wydrukowano w wersji czarno-białej. Należy pamiętać o tym, że każdy papier ma swój własny kolor, a rysunek ołówkiem na papierze to - wbrew pozorom - nie szara czy czarna kreska na białym tle. Witkacy często rysował na kartkach w linie czy w kratkę, które były np. fioletowawe (Mnich walczący z obtędem z 1924 roku); dzisiaj papier bywa pożółkły i dodaje rysunkowi „wartości starożytniczej” (zob. il. 11).Z kolei kompozycje 
wykonane węglem mają barwne sygnatury (np. Portret Jadwigi Janczewskiej pod parasolem z 1913 roku, własność prywatna).

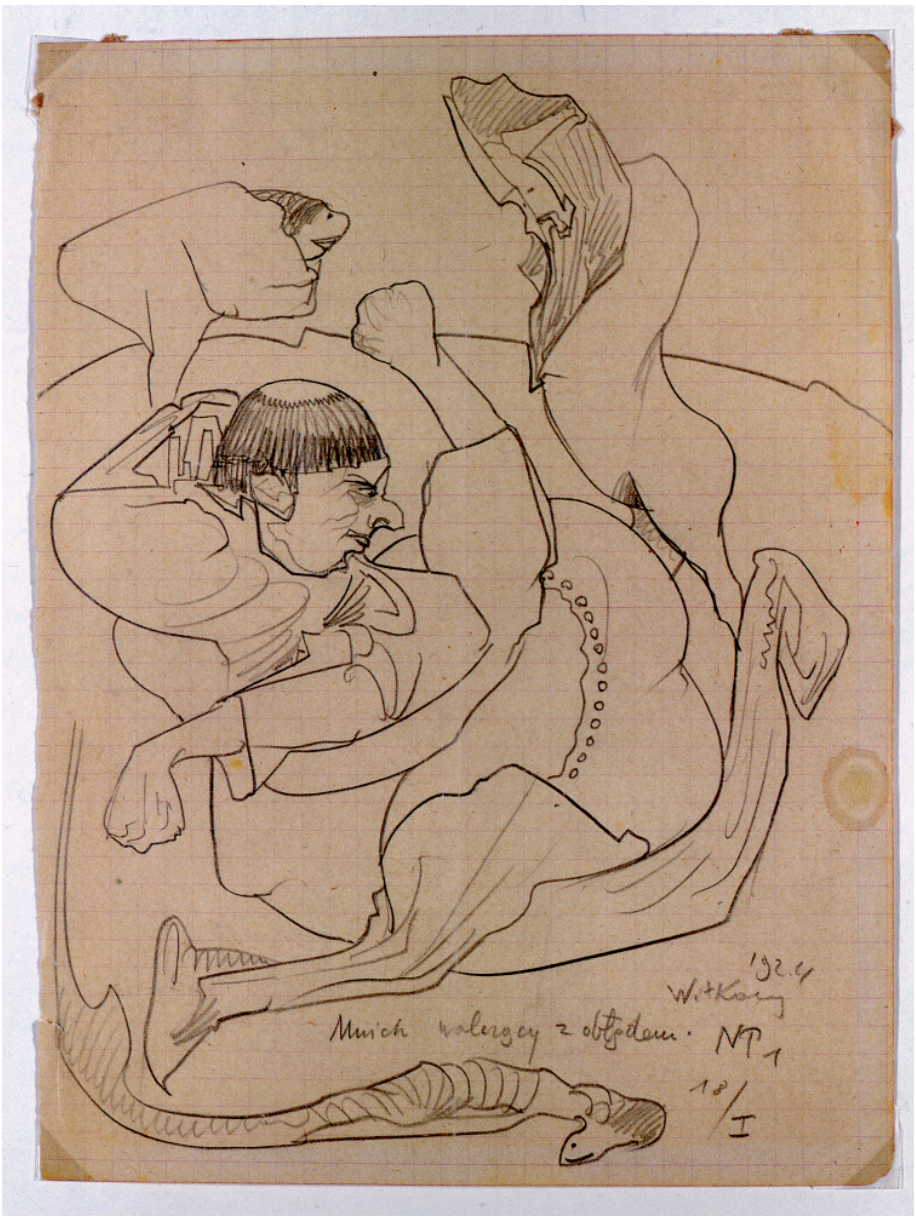

Il. 11. Mnich walczacy z obtędem, 1924, ołówek, Muzeum Pomorza Środkowego, nr inw. MPŚ-M/638

Odwzorowanie barw to osobne zagadnienie, które poruszano już w publikacjach, w tym także w materiałach dotyczących Witkacego ${ }^{37}$. Warto może tylko w skrócie przypomnieć, że kolor obrazu zmienia się w zależności od oświetlenia: inny jest w świetle dziennym, a inny w sztucznym. Podczas wykonywania zdjęć przeznaczonych do reprodukcji dzieła są oświetlane specjalnymi silnymi reflektorami i już to sprawia, że ich kolory wyglądają inaczej.

Książka Piotra Piotrowskiego Stanistaw Ignacy Witkiewicz ${ }^{38}$ została ukończona w 1984 roku; ważniejsze opracowania opublikowane po złożeniu jej do druku są wymienione w ostatniej części bibliografii. Wydano ją w serii bez nazwy, poświęconej malarzom polskim (według informacji na skrzydełku obwoluty miały ukazać się opracowania dotyczące Leona Wyczółkowskiego, Konrada Krzyżanowskiego, Tymona Niesiołowskiego i innych), publikowanej przez Krajową Agencję Wydawniczą w Warszawie.
Walorem książki jest dobór reprodukcji, wśród których znalazło się całkiem sporo rzadko publikowanych prac Witkacego, np.: Dziewczynka Śmierdzinóżka w rozmowie zpachnacym gadem (il. 132), Portret pani Baborowskiej ${ }^{39}$ (il. 127), Portret doktora Pakowskiego (il. 60) i Portret mężczyzny (il. 50). Szkoda, że ze stu trzydziestu trzech ilustracji zaledwie siedemdziesiąt pięć jest kolorowych. Powyższa uwaga ma jednak nieco ahistoryczny charakter - nie należy zapominać, że książka ukazała się w czasach, w których dostęp do ilustracji był dużo trudniejszy: nie było internetu i skanerów, czarno-białe odbitki kserograficzne były stosunkowo drogie, robienie zdjęć wymagało przynajmniej podstawowych umiejętności, zatem miłośnik twórczości Witkacego (czy dowolnego innego artysty) nie mógł liczyć na samodzielnie sfotografowanie aparatem cyfrowym czy telefonicznym obrazu eksponowanego w muzeum.

Książka ma format zbliżony do kwadratu $(267 \times 250$ mm - wymiar płóciennej okładki). Tekst jest złożony w dwóch kolumnach; na stronie jest jedna lub dwie ilustracje (tylko raz aż cztery zdjęcia), rozmieszczone starannie od strony plastycznej, przykłady prac na rozkładówki zostały dobrze dobrane. Gdy publikację tylko się kartkuje czy przegląda, to taka koncepcja nie przeszkadza, a nawet więcej - sprzyja dobremu odbiorowi. Gorzej czyta się tak przygotowaną książkę, ponieważ niemal przy każdym opisie dzieła trzeba wertować jedną bądź kilka kartek. A właśnie opisy poszczególnych prac Witkacego są jednym z mocnych punktów książki. Dobrze, że w tekście są odsyłacze do poszczególnych ilustracji.

Lata dziewięćdziesiąte to w albumologii witkacologicznej całkiem bogaty okres, tylko w 1990 roku ukazały się dwie bardzo ważne książki. Na miano edycji krytycznej materiału wizualnego wśród albumów o twórczości Witkiewicza zasługuje Katalog dziet malarskich ${ }^{40}$ opracowany przez Irenę Jakimowicz we współpracy z Anną Żakiewicz. Wydawnictwo towarzyszyło retrospektywie z przełomu grudnia 1989 i lutego 1990 roku, stanowi jednak samoistną publikację. Merytorycznie książka jest po prostu bezcenna: katalog wraz $\mathrm{z}$ indeksem osób portretowanych, rozwiązaniem skrótów stosowanych przez Witkacego, kalendarium i bibliografia, wstęp i słowo o Witkacym pióra Jakimowicz są tłumaczone też na język angielski. Na 3073 skatalogowane pozycje (w sumie składają się na nie 2074 prace i 799 wzmianek - są to wszystkie prace, do jakich udało się wówczas dotrzeć) w dziale ilustracji pomieszczono 23 kolorowe (zaledwie) i 635 czarno-białych reprodukcji. Można rzec, że 657 reprodukcji stanowi komponent obrazowy do mniej niż jednej trzeciej pozycji. 
To, co jest atutem katalogu, stanowi jednocześnie jego mankament: zebranie tak dużej liczby prac w jednej publikacji wpłynęło znacząco na formę ich podania do druku. Dobór ilustracji warunkuje chronologia, temat oraz ich ksztatt. Partia ilustracyjna zawiera od czterech, pięciu, sześciu do najczęściej dziewięciu (w wypadku stojących prostokątów) reprodukcji wypełniających z reguły szczelnie całe strony. Przy portretach (i formacie książki $240 \times 295$ mm, czyli pomniejszony B4 lub poszerzony A3) taka siatka się sprawdza. Najmniej fortunnie prezentuje się za to układ rysunków, których reprodukcje są wielkości znaczków pocztowych, do oglądania z lupą. Na przykład na przedostatniej stronie Jan Heydrich (opracowanie graficzne i redakcja techniczna) ułożył ich aż jedenaście, ale i tak pozostało jeszcze sporo pustego miejsca (zob. il. 12). Projekt graficzny wcześniejszych stron również zaskakuje niewykorzystaniem wolnej przestrzeni kosztem rozmiaru reprodukcji rysunków (zob. il. 13). Widocznie dla redaktora technicznego ważniejsze było zmieszczenie się na czterdziestu czterech kartach (pięć i pół składki). Można też ubolewać, że tylko dwadzieścia trzy prace są podane w kolorze.

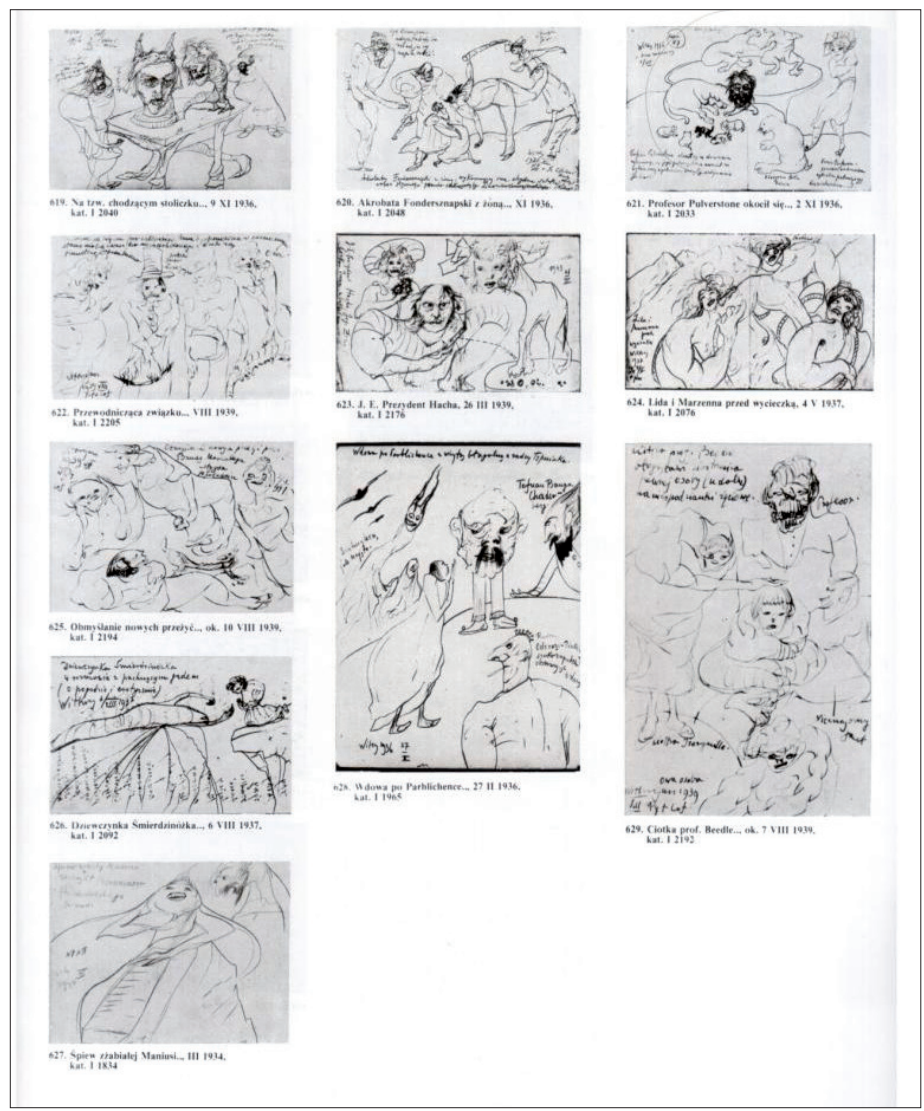

Il. 12. Strona z rysunkami 619-629 ze Stanistaw Ignacy Witkiewicz (1885-1939). Katalog dziet malarskich, oprac. I. Jakimowicz przy współpracy A. Żakiewicz, Warszawa 1990
Z perspektywy dwudziestu pięciu lat aktywności witkacologów, publikacji, a przede wszystkim nowych znalezisk, można rzec, że obecnie możliwe byłoby rozszerzenie obrazowego komponentu do Katalogu dziet malarskich. Bogatego materiału dostarcza działalność domów aukcyjnych - sama tylko Agra-Art do maja 2014 roku wystawiła osiemdziesiąt pięć dzieł sztuki (pastele, oleje, węgle) tego autora ${ }^{41}$, odrębnym pytaniem byłoby, ile z nich nie było dotąd reprodukowanych czy w ogóle znanych, jak autoportret z samowarem z 1917 roku.

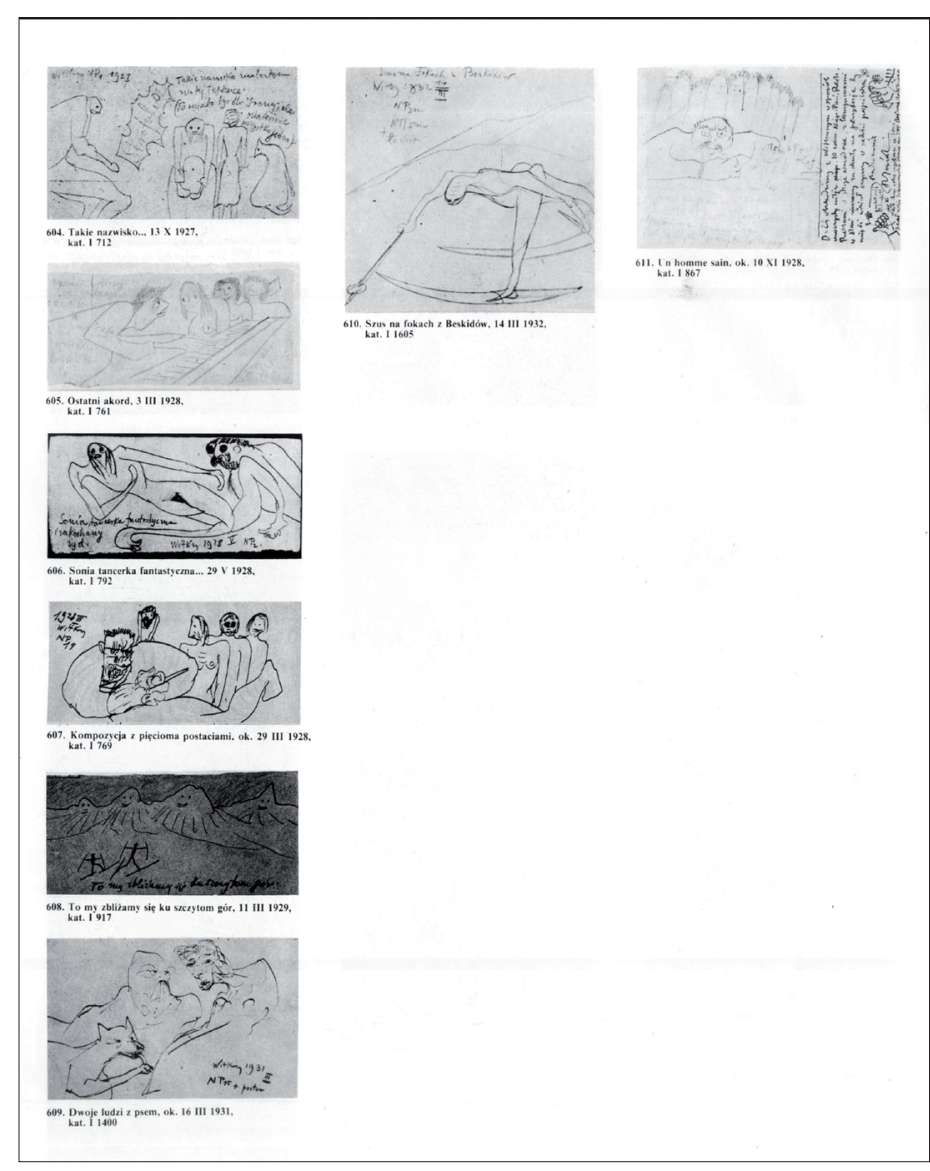

Il. 13. Strona z rysunkami 604-611 ze Stanistaw Ignacy Witkiewicz (1885-1939). Katalog dziet malarskich, oprac. I. Jakimowicz przy współpracy A. Żakiewicz, Warszawa 1990

Lepszym pomystem edycyjnym niż tylko nowe ilustracje byłby oczywiście postulat zaktualizowania całości. Irena Jakimowicz we wstępie z pokorą (choć i świadomością ogromu wykonanej pracy) pisała, że wobec faktu, iż na początku lat trzydziestych Witkacy ogłosił narysowanie 5000 portretu, katalog jest etapem prac „otwartym na kontynuację”. To wielkie zamierzenie staje się coraz bardziej potrzebne.

W 1990 roku ukazał się album, a właściwie więcej niż album, witkacologiczne kompendium (ss. 368) Anny Micińskiej po polsku, francusku i angielsku. W Witkacy. Stanistaw Ignacy 
Witkiewicz. Życie i twórczośćs brak roku wydania, Biblioteka Narodowa dla wydawnictwa anglojęzycznego podaje 1990, dla polskiego i francuskiego 1991 rok, na stronie www.witkacologia.eu umieszczono edycję pod 1990 rokiem. Oprócz wstępu Micińskiej z 1985 roku znajdziemy tam działy: $Z$ dziejów rodziny, Kalendarium, $Z$ rodzinnego albumu, Malarstwo, Teatr, Witkacego teatr wyobraźni, a także Witkacego na świecie oraz bibliografię opracowaną przez Janusza Deglera. W każdym dziale oprócz tekstów autorskich znajdziemy archiwalia - listy pisane przez małego Stasia, potem Stanisława Ignacego Witkiewicza, wybór fragmentów z listów Stanisława Witkiewicza, rodziny; wszystko to bogato okraszone pracami plastycznymi każdego kalibru, fotografiami, także archiwalnymi i rodzinnymi, fragmentami prac literackich, filozoficznych, krytycznych czy wspomnień innych osób o Witkacym.

Wartość przekazu słownego i obrazowego w tej książce jest olbrzymia. Publikacja stanowiła i stanowi odkrycie, mnóstwo nowych nieznanych prac, archiwalia: listy, rękopisy, druki ulotne (choćby kultowy druk Rozbioru moczu uzupełniony przez Witkacego, il. 123) czy notatki oraz rysunki w naturalnych barwach w wielkości umożliwiającej kontemplację $(2+2$ lub jeden na całą stronę). W wypadku prac plastycznych można narzekać jedynie na drukowanie wszystkiego na spad.

W 1996 roku Beata Zgodzińska-Wojciechowska wraz z Anną Żakiewicz wydały album Witkacy. Kolekcja dziet Stanistawa Ignacego Witkiewicza w Muzeum Pomorza Środkowego w Stupsku ${ }^{43}$ (także wersja angielska, francuska i niemiecka). Biografię malarza i dzieje kolekcji opisała Anna Żakiewicz, Beata Zgodzińska odpowiadała za katalog (publikacja obejmuje nabytki do końca 1995 roku) i słupskie imprezy poświęcone Witkacemu. Autorki wspólnie przygotowały kronikę życia Witkacego w kontekście wydarzeń artystycznych w Polsce, na świecie i wydarzeń historycznych.

Pod względem podania materiału ilustracyjnego mamy tu do czynienia z klasycznym albumem, niezbyt szeroko na szczęście wykorzystującym rozwiązanie druku na spad. Żywe, ale nie przejaskrawione (jak niestety często się zdarza) kolory pasteli pozwalają na spokojne cieszenie się zawartością. Drugą, acz rzadszą skrajnością, jest przytłumienie kolorów, co także współcześnie się zdarza - np. w albumiku poświęconym Witkacemu z serii „Wielka Kolekcja Sławnych Malarzy” firmy Oxford Educational sp. z o.o. (zob. il. 14) ${ }^{44}$.

Powinno się tylko odnotować niecną praktykę wydawnictwa - w 1996 roku gustowną granatową kartonową okładkę z lakierowanym tłoczeniem „Witkacy” zaopatrzono w obwolutę z polatującą nad górami głową Eugeniusza Lorka z 1937 roku. Drugie wydanie tej samej publikacji z 2001 roku (którego współwydawcą było Wydawnictwo Naukowe PWN) ma już inną obwolutę - z portretem Zofii Nawrockiej z 1929 roku w dekoracyjnym, różowym szalu. Posunięcie z pozoru znakomite ze względów marketingowych wprowadza jednak zgłodniałych nowości witkacofilów w błąd, a szerzej rzecz ujmując podważa zaufanie do oficyn wydawniczych. Książki różnią się jedynie kolorami okładek, wyklejek i obwolutami.

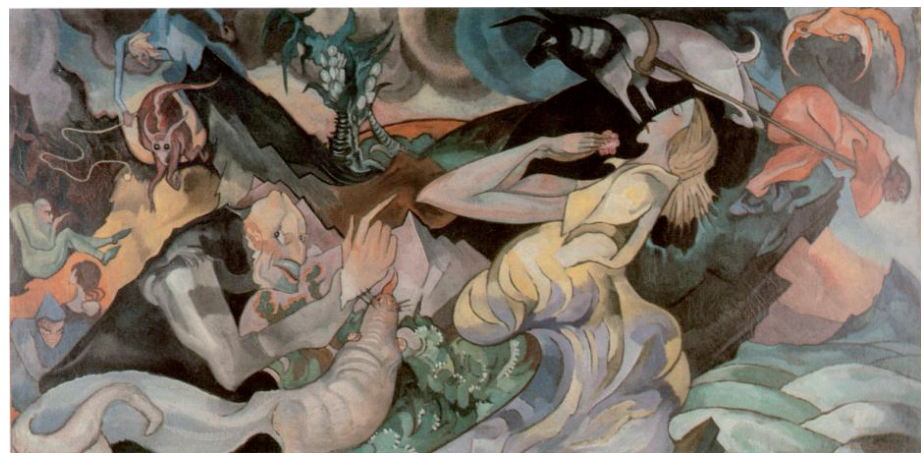

Il. 14. Kuszenie świętego Antoniego II ze Stanistaw Ignacy Witkiewicz - Witkacy. 1885-1939 ([b. red.], Oxford, Poznań 2007, s. nlb.)

W pracy nad książką, a zwłaszcza nad publikacją typu albumowego, bardzo istotny jest dobór reprodukcji. Warto uwzględnić, które dzieła już zostały zreprodukowane w przekrojowych ilustrowanych wydawnictwach o zasięgu ogólnopolskim: po to, by uniknąć sytuacji, w której pewne prace wykorzystywane są często, a inne prawie wcale. Doświadczenia z czasów, kiedy było się tylko czytelnikiem i „oglądaczem” książek, w których często były powtarzane te same reprodukcje, wpływają na naszą teraźniejszą praktykę zawodową.

Beata Zgodzińska, przystępując jesienią 2003 roku do wyboru ilustracji do książki Dziwność istnienia. The Strangeness of Existence przygotowywanej przez wydawnictwo Parma Press ${ }^{45}$, najpierw spisała, jakie dzieła Witkacego były reprodukowane we wcześniej wydanych książkach: Witkacy - malarz Ireny Jakimowicz (1985, wydanie drugie 1987), Stanistaw Ignacy Witkiewicz Piotra Piotrowskiego (1989) i Witkacy. Stanistaw Ignacy Witkiewicz. Życie i twórczość Anny Micińskiej (1990). Ów spis miał formę tabeli - i to bardzo tradycyjnej, gdyż wykonanej odręcznie. Drugim materiałem, ale już o charakterze pomocniczym, była w miarę pełna bibliografia do każdego dzieła z kolekcji Muzeum Pomorza Środkowego w Słupsku, gdyż zgodnie z ustaleniami z wydawcą oraz z dyrektorem muzeum, większość materiału ilustracyjnego miała pochodzić właśnie ze zbiorów słupskich.

Dysponując tymi informacjami, można było tak dobrać reprodukcje, by - bez szkody dla merytorycznej zawartości książki - maksymalnie uatrakcyjnić ją dla tych wszystkich, 
którzy w domowych biblioteczkach mieli już wspomniane powyżej publikacje wydane przez duże wydawnictwa. Oba katalogi rozumowane słupskiej kolekcji (edycja z 1987 roku; a także album z 1996, wydanie drugie z 2001 roku) nie stanowiły w tym wypadku dobrego punktu odniesienia, gdyż były to wydawnictwa o innym charakterze. Ostatecznie, z przyczyn niezależnych i od wydawcy, i od autorki, w albumie nie znalazły się prace ze zbiorów Muzeum Narodowego w Warszawie i Muzeum Narodowego w Krakowie. Z jednej strony może trochę szkoda, że do tej pierwszej publikacji ściśle albumowej (niektórzy wydawcy za „album” uważają książki z jedną dużą reprodukcją na jednej stronie) nie trafiło żadne dzieło Witkacego ze zbiorów tych dwóch szacownych placówek. Ale może nie ma czego żałować, gdyż dzięki temu zostało pokazanych kilka prac z muzeów regionalnych oraz kilka mniej znanych ze Słupska.

Trzeba podkreślić dobrą współpracę z wydawnictwem, i to na każdym etapie powstawania książki. Oczywiście, były kwestie sporne czy dyskusyjne, jak np. upór autorki w kwestii umieszczenia po kolei przykładów poszczególnych typów portretów, zgodnie z zapisem w regulaminie Firmy Portretowej. Ku zgrozie graficzki, pani Anety Czarneckiej, sportretowane przez Witkacego Maria Nawrocka (s. 75) i Irena Krzywicka (s. 77) patrzą w stronę zewnętrznych krawędzi kartek.

Autorka poniosła z kolei porażkę, gdy wydawnictwo mimo brania pod uwagę różnych propozycji tytułu - ostatecznie opublikowało książkę pod tytułem mało adekwatnym do przyjętego w tekście sposobu opowiadania o Witkacym. Według pierwszych ustaleń, krótkie komentarze miały towarzyszyć wybranym ilustracjom - na etapie składania okazało się, że trzeba zweryfikować tę koncepcję, gdyż niedobrze wyglądało, gdy pod mniej więcej połową reprodukcji były tylko dane podstawowe, a pod drugą połową - dane i komentarz. Nolens volens, trzeba było komentarze dopisać...

Wydawnictwo Parma Press ze zrozumieniem przyjęło konieczność podania muzealnego numeru inwentarzowego obiektu. Bezspornie i jednoznacznie identyfikuje on dzieło, o czym łatwo można się przekonać: wystarczy tylko uświadomić sobie, że w zbiorach słupskich jest dziesięć portretów Michała Choromańskiego, dwadzieścia trzy - Heleny Białynickiej-Biruli, czternaście - Neny Stachurskiej, w tym dwa z 24 lutego 1930 roku [!].

Współcześnie coraz więcej książek jest wydawanych dzięki wsparciu ze strony urzędów, biur promocji, organizacji turystycznych, zatem na ostateczny ich kształt mają wpływ różne osoby i instytucje. Wydana w 2010 roku dwujęzyczna książka Witkacy w Stupsku. Firma Portretowa „S. I. Witkiewicz” to przykład publikacji ${ }^{46}$, w której określona przez wydawcę - Urząd
Miejski w Słupsku - szata graficzna nie do końca się sprawdziła. Zastosowanie szarego tła dla kolumn z tekstem angielskim, umieszczonych jako kolumny wewnętrzne, dało dobry efekt (zob. il. 15). Kompozycja osiowa, warunkowana podziałem karty na połowy szarą i białą, pozwoliła na ciekawy projekt stron działowych i tytułowych - Agnieszka Szczepaniuk-Araszkiewicz i Mariusz Wojciechowski grają tym, co wspólne i oddzielne. Analogiczne zastosowanie podwójnego tła jest znacznie mniej fortunne na stronach z reprodukcjami, gdyż każda ilustracja wygląda tak, jakby jej połowa bliższa grzbietu książki była ciemniejsza. Niewiele pomogło wprowadzenie wąskiego białego marginesu wzdłuż krawędzi reprodukcji (zob. il. 16).Z drugiej strony, dzięki sfinansowaniu druku przez słupski magistrat, możliwe było wydanie książki o Firmie Portretowej napisanej kilka lat wcześniej, na wydanie której słupskie muzeum nie znalazło środków.

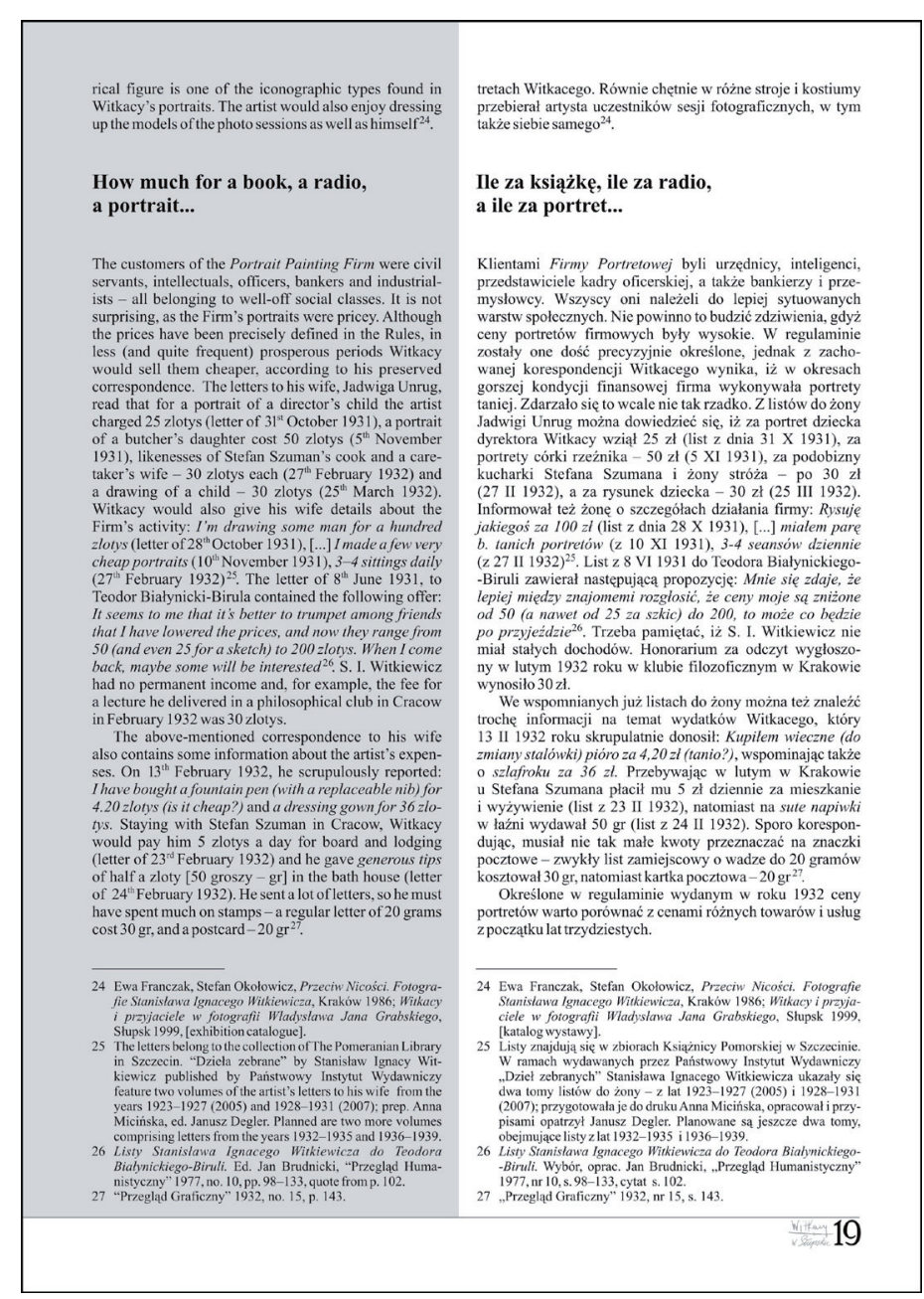

Il. 15. Strona 19 z książki B. Zgodzińskiej Witkacy w Stupsku. Firma Portretowa „S. I. Witkiewicz” / Witkacy in Stupsk. The „S. I. Witkiewicz” Portrait Painting Firm (Słupsk 2010) 


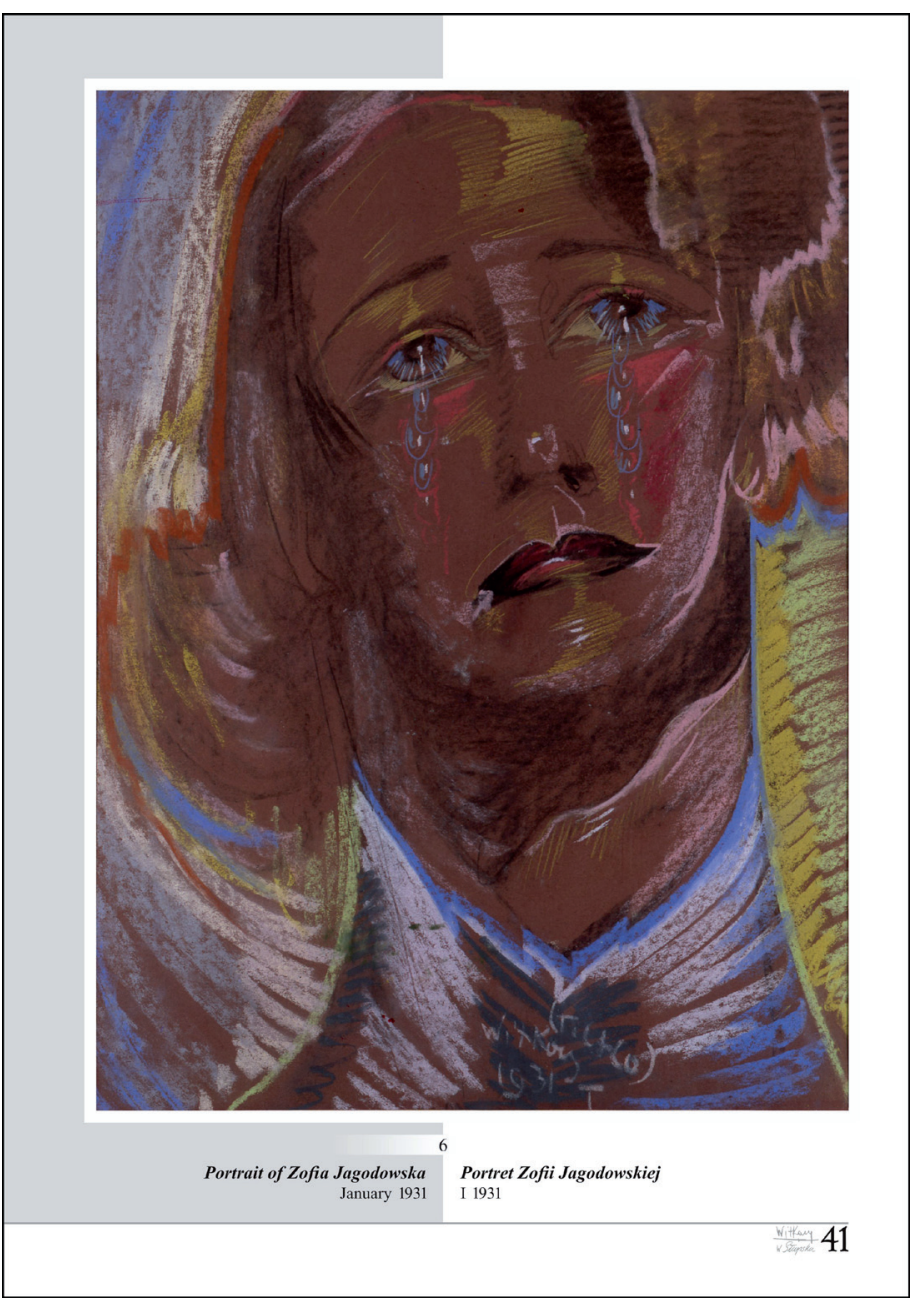

Il. 16. Strona 41 z książki B. Zgodzińskiej Witkacy w Stupsku. Firma Portretowa „S. I. Witkiewicz” / Witkacy in Stupsk. The „S. I. Witkiewicz” Portrait Painting Firm (Słupsk 2010)

Warto także wspomnieć, że temu albumikowi przytrafiło się zamieszanie z okładką, jakie zdarza się nieczęsto. Strona pierwsza wykorzystuje (zmodyfikowany także na stronie działowej) motyw graficzny całej publikacji, a mianowicie portret Marii Nawrockiej z 1929 roku w typie podstawkowym Alcoforado (zob. il. 17). Piękna głowa modelki wydobyta została $\mathrm{z}$ rozbielonego tła przez lakier punktowy, zbliżoną do naturalnej kolorystykę pastelu oraz złotą obwódkę. Złotą pisanką, imitującą charakter pisma artysty w sygnaturze, wykonano napisy po obu stronach postumentu Witkacy in Stupsk / Witkacy w Stupsku, taki też jest zresztą tytuł edycji (który ewentualnie miał stać się pierwszą częścią tytułu serii książek traktujących o Witkacym w Słupsku). Oszczędność informacji do przyjęcia. Czytelnik zostaje zaskoczony dopiero stroną czwartą, gdzie oprócz numeru ISBN pojawia się nazwisko autorki i podtytuł Firma Portretowa / The Portrait Painting Firm "S. I. Witkiewicz” (zob. il. 18). Chyba każdy sądzi, że okładki zostały zamienio-

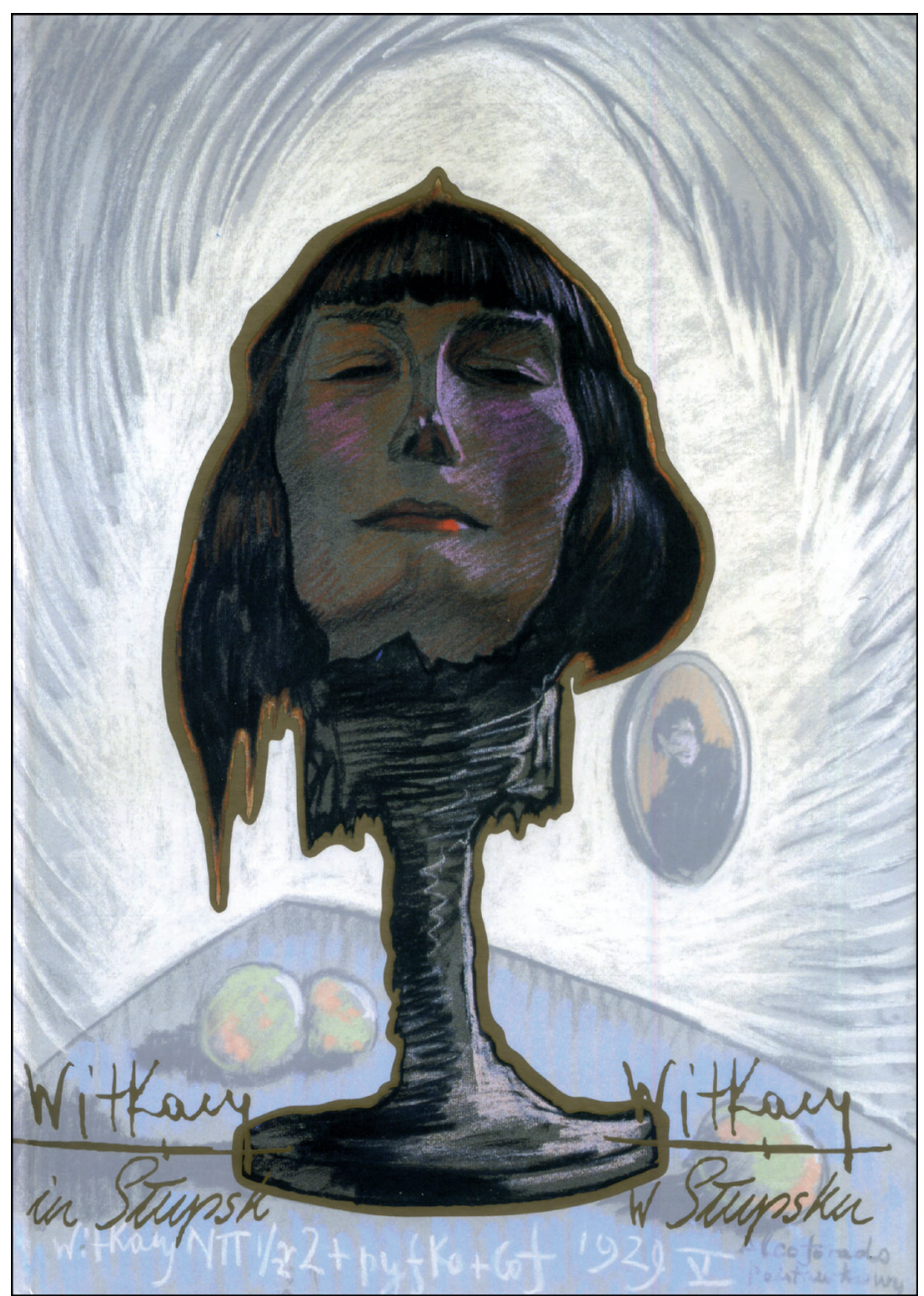

Il. 17. Pierwsza strona okładki książki B. Zgodzińskiej Witkacy w Stupsku. Firma Portretowa „S. I. Witkiewicz” / Witkacy in Stupsk. The „S. I. Witkiewicz” Portrait Painting Firm (Słupsk 2010)

ne - nic podobnego, to był celowy i świadomy zabieg wydawcy i autorki projektu! I żadne argumenty nie pomogły.

Zapowiedziane we wstępie Pamiętanie jesienia z 2011 roku to wydawnictwo towarzyszące wystawie dwudziestu pasteli i olejów Witkiewicza (czyli wszystkich obrazów w zbiorach Muzeum Narodowego w Poznaniu), a także jego fotografii ze zbioru Ewy Franczak i Stefana Okołowicza oraz Galerii Piekary w Poznaniu. Wojciech Suchocki zaplanował wystawę wspólnie z wieczornicą, w trakcie której czytano Pożegnanie jesieni oraz słuchano kompozycji muzycznej IP / Tajemnica Istnienia Bogdana Mizerskiego. Książeczka w twardej oprawie, w nietypowym formacie $(185 \times 285 \mathrm{~mm})$ wszystkie te wątki zawiera: na wyklejce trzeciej strony okładki wklejono narożnik na płytę z nagraniem, zaś publikacja składa się z dwudziestu reprodukcji olejów i pasteli umieszczonych na stronach nieparzystych oraz fragmentów powieści na stronach parzystych. Stanowi to czytelny sygnał, że autorka projektu graficznego Lidia Żurad 
pierwszeństwo dała obrazowi. Zaszło to jednak za daleko. Karty z ilustracjami rozplanowano znakomicie: format książki pasuje do typowego dla pasteli stojącego prostokąta, obrazy otacza spory margines, dane katalogowe są rozmieszczone przejrzyście. Karty z tekstem Pożegnania jesieni potraktowano bardzo po macoszemu: są one w odcieniach beżu z poddrukiem zawierającym ledwie widoczne Witkacowskie miny z fotografii. Tekst wyrównano do lewego marginesu, ale co najgorsze lewy margines niemal nie istnieje, w skrajnych wypadkach kolumnę z tekstem dzielą od skraju papieru trzy [!] milimetry (zob. il. 19). Tylko jedna ze stron parzystych została w całości zapisana (zob. il. 20), w pozostałych kolumny z tekstem, zdecydowanie za szerokie i nieproporcjonalne, zajmują nawet mniej niż pół wysokości stronicy. Zrobiono tak, by twarz z fotografii mieściła się pod tekstem. Czasem jednak widać tylko usta (s. 24). Wydaje się, że lepiej było darować sobie zauważalne dopiero przy wnikliwszym przyjrzeniu się fotografie i rozsądniej opracować strony z tekstem.

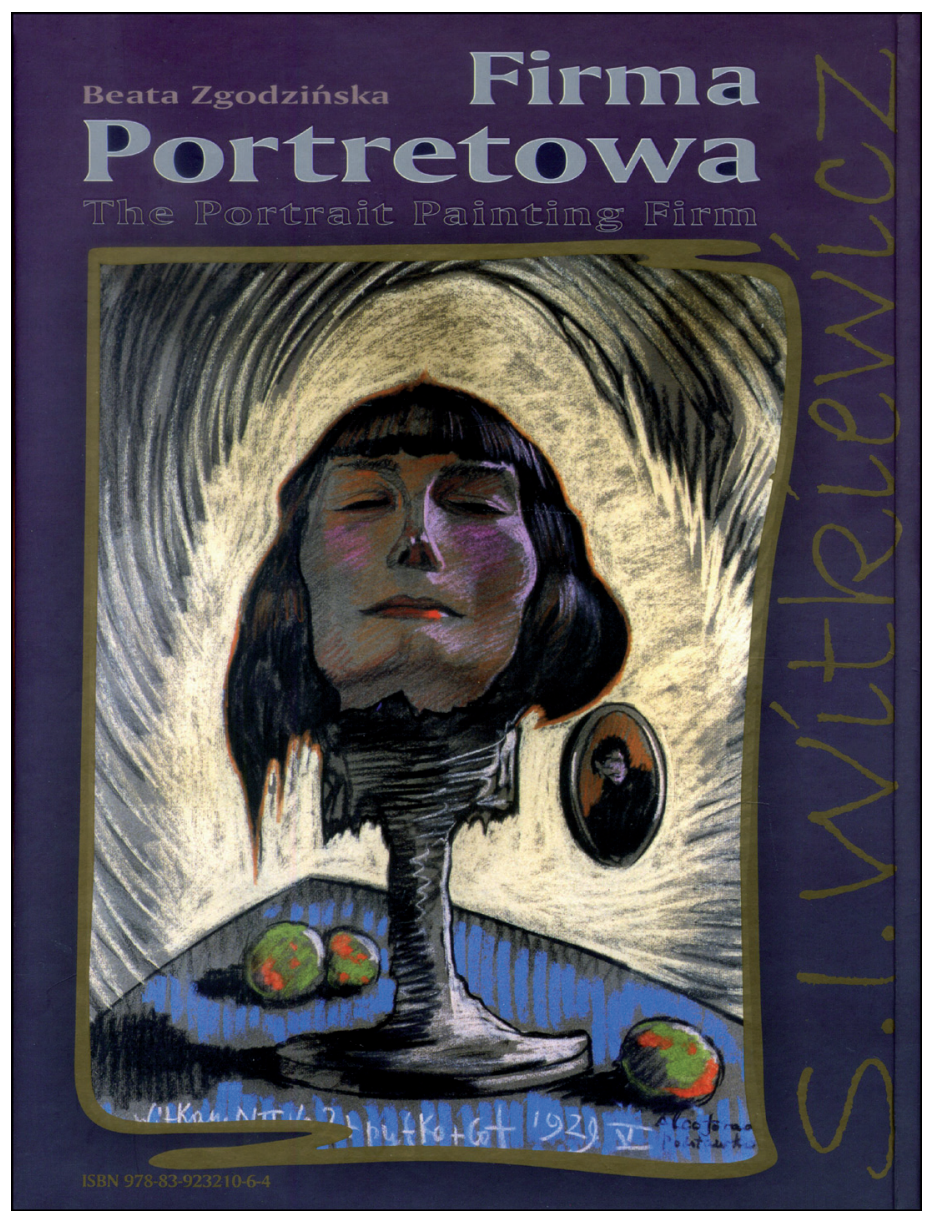

Tu także trzeba poczynić konieczną, aczkolwiek oczywistą uwagę, że inaczej przygotowuje się wydawnictwo okolicznościowe, jedynie towarzyszące jakiemuś wydarzeniu, a inaczej solidny album czy katalog dzieł wszystkich. Osobną sprawą jest chęć kontestacji reguł edytorskich, wszak już w teatrze w latach sześćdziesiątych sądzono, że im dziwniej gra się Witkacego, tym lepiej. Warto jednak nie kończyć apeli o „dobrą robotę”.

Anna Żakiewicz pisze teksty kompetentne i jasne, bez niepotrzebnych udziwnień (np. obcych wyrażeń zamiast polskich, jak też skomplikowanych konstrukcji składniowych, niekiedy błędnie używanych w tekstach historyków sztuki), dzięki czemu po prostu dobrze się je czyta.

Tym większa szkoda, że w jej wydanej w 2012 roku książce Witkacy ${ }^{47}$ autor opracowania graficznego Lech Majewski uczynił naprawdę wiele, by tekst ten czytało się z kłopotami (zob. il. 21). Wyróżnienie cytatów aż trzema elementami: szarym tłem, ścieśnionym pismem, szarą odręczną kreską sugerującą zaznaczenie ołówkiem, to niczym nieuzasadniona rozrzutność typograficzna. Istotnym mankamentem jest dobór kroju pisma, w której „b” i „6” są nie do odróżnienia, a światło przed „j” może niekiedy budzić wątpliwości, z iloma wyrazami mamy do czynienia: z jednym czy z dwoma. Tekst jest dwujęzyczny, złożony w dwóch kolumnach; na niektórych stronach kolumna angielska ma mniejszy margines górny niż polska, na kilku jest poniżej (a nie obok, jak na większości), na niektórych stronach kilka (na stronie 72: dziewięć!) lub kilkanaście wierszy tekstu rozdzielono sporych rozmiarów reprodukcją. Wreszcie przypisy - jakby dodane w ostatniej chwili, umieszczone pod kątem prostym do tekstu [!].

Niewątpliwą zaletą książki są duże reprodukcje (szkoda tylko, że te umieszczone na rozkładówkach nie zawsze są w całości czytelne, z racji braku zwiększonego wewnętrznego marginesu: tułów Ewy ze Stworzeniu świata wypadł akurat w miejscu łączenia kart). Ilustracjom towarzyszą podpisy zawierające następujące dane: tytuł, czas powstania, technikę, wymiar i właściciela. Choć zestaw reprodukcji w znacznym stopniu powtarza zawartość albumików tej autorki z 2004 i 2006 roku wydanych w mniejszym formacie ${ }^{48}$, znajdziemy tu i takie rarytasy jak kolorowy, nigdzie dotąd niereprodukowany autoportret z 1918 roku z prywatnej kolekcji. Gdy wielkość pracy nie jest znana, jest to odnotowane (s. 24). Reprodukcje dzieł omawianych i analizowanych w tekście są umieszczone na tych samych lub na sąsiednich stronach, co znacznie ułatwia czytanie.

Il. 18. Czwarta strona okładki książki B. Zgodzińskiej Witkacy w Stupsku. Firma Portretowa "S. I. Witkiewicz" / Witkacy in Stupsk. The „S. I. Witkiewicz” Portrait Painting Firm (Stupsk 2010) 


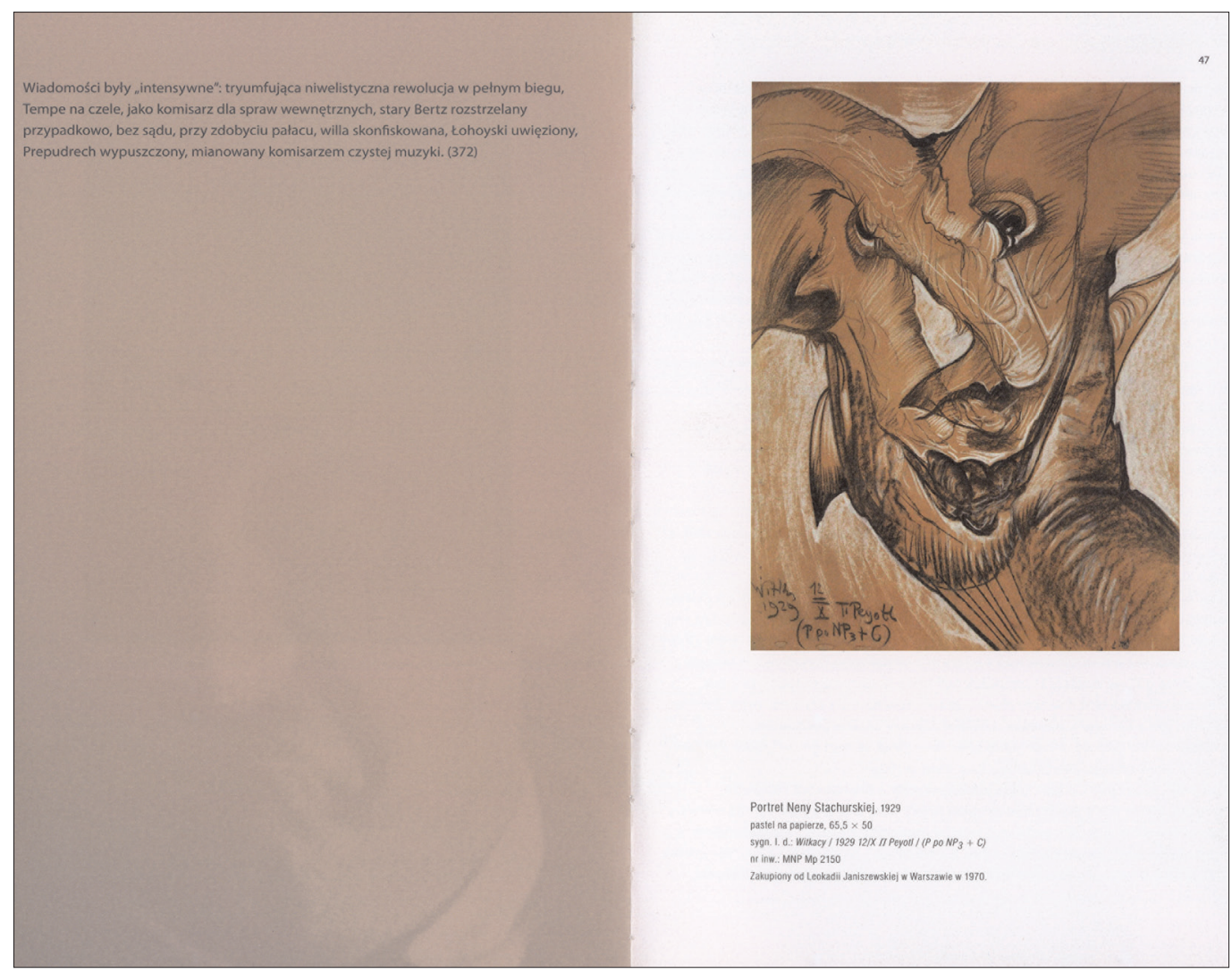

Il. 19. Strony 46 i 47 z Pamiętania jesienią (red. W. Suchocki, Poznań 2011)

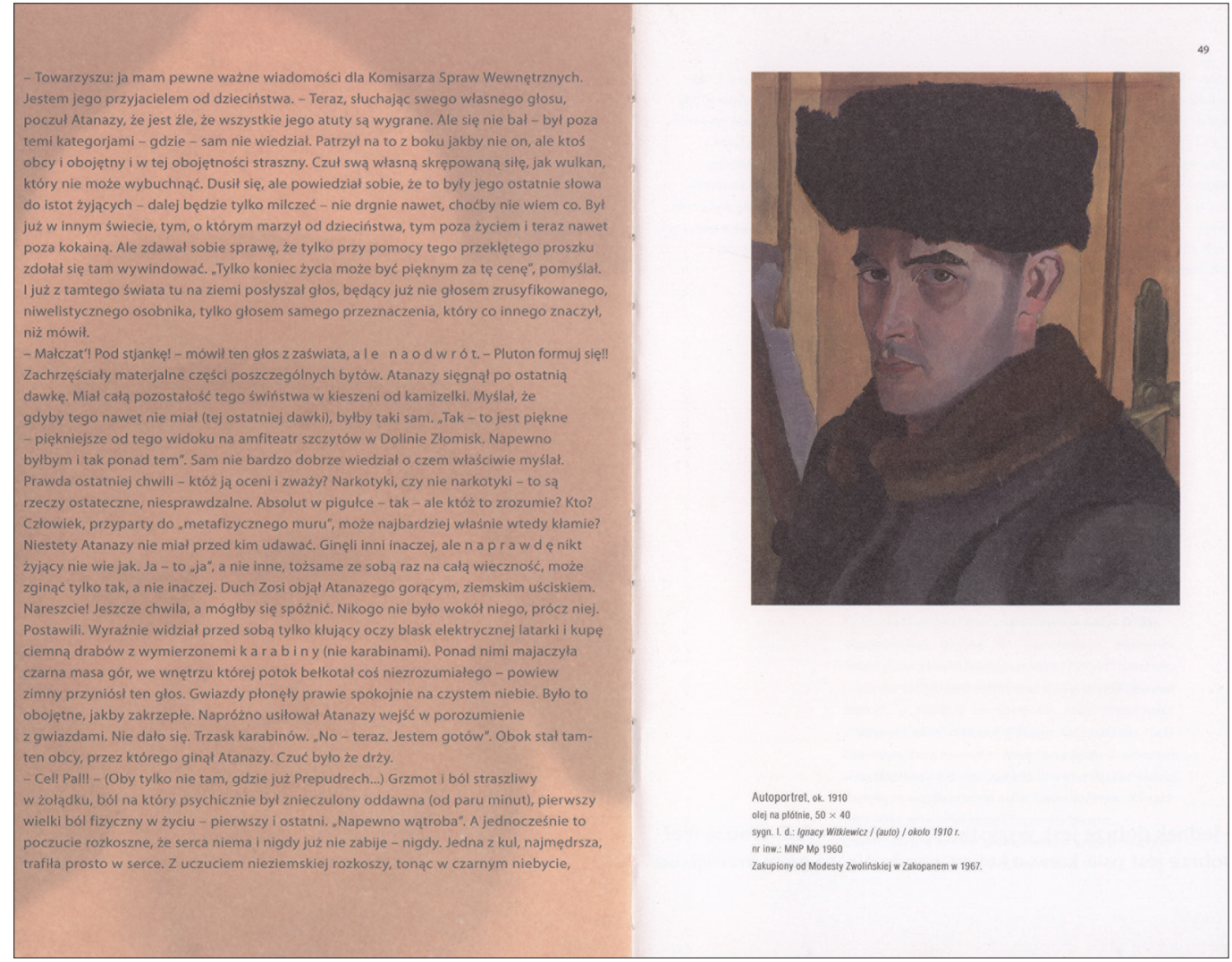

Il. 20. Strony 48 i 49 z Pamiętania jesienia (red. W. Suchocki, Poznań 2011) 


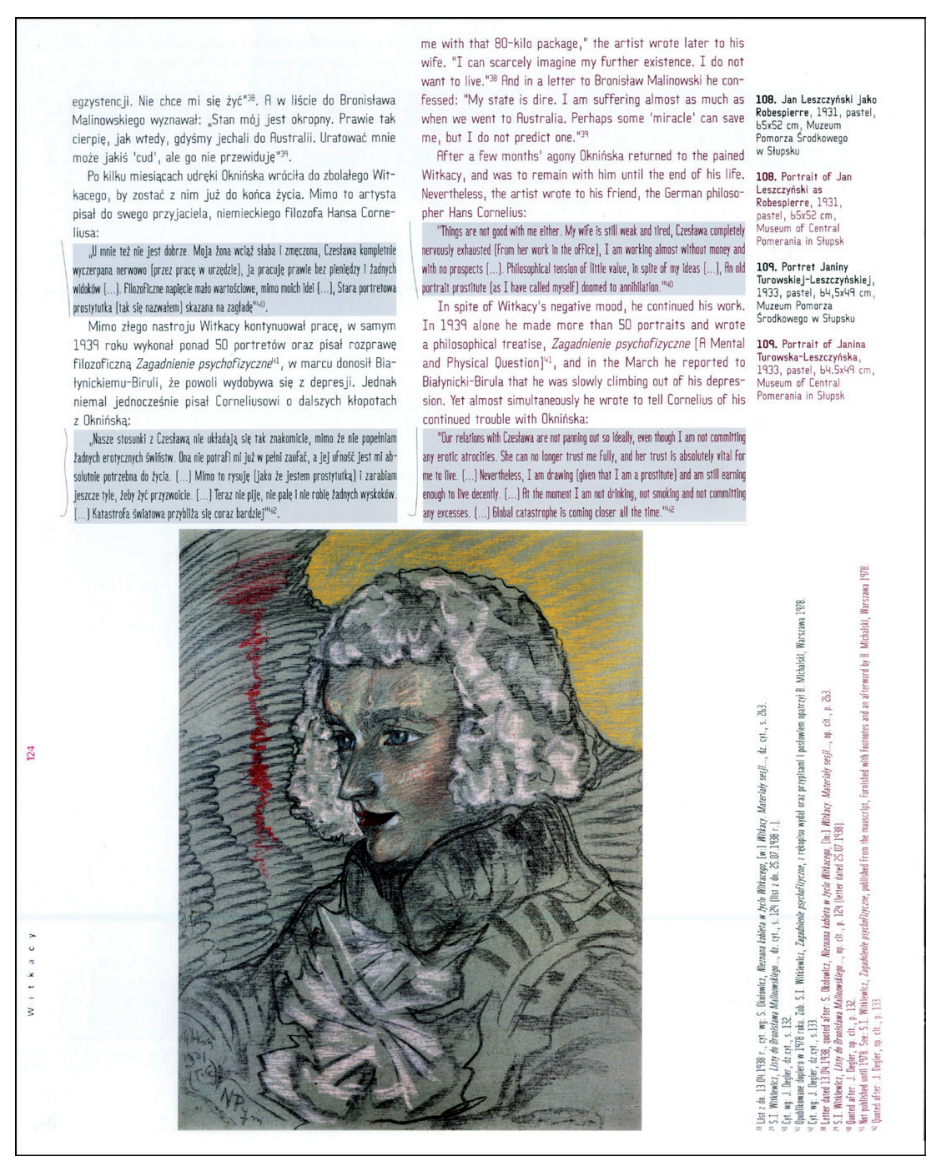

Il. 21. Strona 124 z książki A. Żakiewicz, Witkacy (Bosz, Olszanica 2012)

\section{Zakończenie}

Tytułem podsumowania: o ogromnej roli wszystkich zaangażowanych w edycje, w których musi być i tekst, i obraz - bo autorzy jednego i drugiego są skazani na redaktorów, wydawców i grafików (lub ogólnie projektantów książek) - nie trzeba nikogo przekonywać. Ale warto przypominać.

Warto też zachęcać redaktorów i edytorów oraz autorów do kontaktowania się z historykami sztuki, konserwatorami dzieł sztuki, muzealnikami czy pracownikami domów aukcyjnych, gdyż osoby te, mając bezpośredni kontakt z dziełem sztuki (a nie tylko z jego reprodukcją), siłą rzeczy inaczej nań patrzą. Nie bez znaczenia jest także i to, że często są to pasjonaci swoich zawodów, a więc delikwenci, którzy - pytani czy nie i tak chętnie opowiadają o tym, czym się zajmują.

lipiec 2014 roku

Key Words: Stanisław Ignacy Witkiewicz (Witkacy), illustrations, reproductions, the artist's paintings and drawings, a catalogue of the artwork collection album, the collection of paintings, the aesthetic side of a publication

Summary: The authors of the article, having looked through about a dozen books which apart from texts contained artworks by Stanisław Ignacy Witkiewicz, decided to share whit the readers their remarks concerning editorship, typography and history of art about publishing the artist's paintings and drawings. Generally, they commented in a chronological order the most important editions from the late 70s and 80s: Stanistawa Ignacego Witkiewicza wiersze i rysunki (Poems and drawings by Stanistaw Ignacy Witkiewicz) by Anna Micińska and Urszula Kenar; Witkacy-malarz (Witkacy-the painter) by Irena Jakimowicz; a catalogue of the artwork collection from Słupsk Stanistaw Ignacy Witkiewicz. Witkacy $1885-1939$ by Anna Krzyżanowska-Hajdukiewicz and Stanistaw Ignacy Witkiewicz by Piotr Piotrowski, as well as the ones from the 90s. Katalog $d z i e t$ malarskich (A Catalogue of Painted Works) by Irena Jakimowicz in cooperation with Anna Żakiewicz, the album Witkacy. Stanistaw Ignacy Witkiewicz. Życie i twórczość (Witkacy. Stanistaw Ignacy Witkiewicz. Life and Works) by Anna Micińska, and two editions of the catalogue Witkacy. Kolekcja dziet Stanistawa Ignacego Witkiewicza w Muzeum Pomorza Środkowego w Stupsku (Witkacy. A Collection of Works by Stanistaw Ignacy Witkiewicz in Muzeum Pomorza Środkowego in Stupsk). Beata Zgodzińska shared many remarks and digressions of the curator of Stupsk collection, responsible for catalogues of collections, exhibitions and numerous publications devoted to Witkacy.

The authors believe that it is always worth to pay attention to the visual aspects of a publication and to raise awareness among editors, technical editors, text compositors and graphic designers about for whom and why they are making a book. The manner of submitting a work of art for printing (bleed, framing, photographing without a frame, colors of the reproduction) not only constitutes the aesthetic side of a publication, but is of fundamental importance for some recipients - art historians or students, for whom the reproductions included in available editions are often a basis for research and elaborations.

${ }^{1}$ W obronie tej bardzo dobrej syntezy można powiedzieć, że pierwsze wydanie z 1952 roku miało status „notatek z wykładów”. Jednak wydania drugie (1957), trzecie (1958) i kolejne z lat 1970, 1981, 1983, 1985 nadal nie zawierały ilustracji.

2S. I. Witkiewicz, 622 upadki Bunga, czyli Demoniczna kobieta, oprac. A. Micińska, posłowie J. Degler, przygotowanie, wybór i opracowanie materiału ilustracyjnego S. Okołowicz, Warszawa 2013, cytat z czwartej strony okładki. Jest sześćdziesiąt sześć prac autorstwa Witkiewicza, obok nich znalazły się fotografie wykonane przez inne osoby.

${ }^{3}$ W. Sztaba, Stanisław Ignacy Witkiewicz. Zaginione obrazy i rysunki sprzed roku 1914 według oryginalnych fotografii ze zbiorów Konstantego Puzyny, Warszawa 1985.

${ }^{4}$ E. Franczak, S. Okołowicz, Przeciw Nicości. Fotografie Stanisława Ignacego Witkiewicza, Kraków 1986.

${ }^{5}$ S. I. Witkiewicz, 622 upadki Bunga, il. na s. 88: Bronisław Malinowski, na s. 197: Irena Solska, na s. 312: Stanisław Zdyb. W spisie ilustracji podano, kto został sportretowany, jak nazywa się w powieści oraz w jakiej technice wykonano reprodukowane dzieło. Na końcu podano zbiorczą informację, skąd prace pochodzą, a także, że wszystkie powstały w latach 1908-1914. Zaciekawieni nowościami, by uzyskać więcej informacji, muszą zwrócić się osobiście do kolekcjonerów. Należy pamiętać, że materiał ilustracyjny podlegał kadrowaniu - 
np. fotografia na s. 441 ukazuje tylko Witkacego i Czerwijowską, bez Marii Witkiewiczowej i Emila Breitera. Por. Przeciw Nicości, nr 104

${ }^{6}$ Idem, Antologia, Kielce 2011 („Poezja Polska”, t. 23)

${ }^{7}$ J. Degler, Witkacego portret wielokrotny. Szkice i materiaty do biografii (1918-1939), Warszawa 2009.

${ }^{8}$ Pamiętanie jesienią, red. W. Suchocki, Poznań 2011

${ }^{9}$ Zdjęcie z kolekcji Ewy Franczak i Stefana Okołowicza zostało mylnie podpisane jako pochodzące z 1930 roku, podczas gdy zgodnie z datowaniem kolekcjonerów (Przeciw Nicości, nr 288) wykonał je Józef Głogowski około 1931 roku.

${ }^{10}$ Encyklopedia wiedzy o książce, red. A. Birkenmajer et al., Wrocław 1971, kol. 952.

${ }^{11}$ F. Trzaska, Poradnik redaktora, Warszawa 1976, s. 84. W nowszej literaturze przedmiotu np. Adam Wolański w Edycji tekstu (Warszawa 2008, s. 226 i n.) skupia się na ilustracjach koniecznych do rozumienia tekstu, a ogólne uwagi Barbary Osuchowskiej z Poradnika autora, tłumacza i redaktora (Warszawa 2011, s. 118 i n.) nie dotyczą reprodukowania dzieł sztuki.

${ }^{12}$ M. Mitchell, S. Wightman, Typografia książki. Podręcznik projektanta, tłum. D. Dziewońska, Kraków 2012, s. 282.

${ }^{13}$ J. Wiercińska, Sztuka i książka, Warszawa 1986, s. 39

${ }^{14}$ Encyklopedia wiedzy o książce, kol. 25.

15 J. Wiercińska, Sztuka i ksiażka, s. 39-40.

${ }^{16}$ F. Trzaska, Poradnik redaktora, s. 86.

${ }^{17}$ Za informację dziękujemy panu Sylwestrowi Ząbkowi z pracowni konserwatorskiej słupskiego muzeum.

${ }^{18}$ Marginalia filozoficzne, red. P. Polit, Warszawa 2004, s. 60

${ }^{19}$ I. Jakimowicz, Witkacy - malarz, Warszawa 1985, il. 27.

${ }^{20}$ Stownik terminologiczny sztuk pięknych. Wydanie nowe, red. K. Kubalska-Sulkiewicz et al., Warszawa 1996, s. 304.

${ }^{21}$ Ibidem, s. 84

${ }^{22}$ Stanisława Ignacego Witkiewicza wiersze i rysunki, wybrały i do druku podały A. Micińska i U. Kenar, Kraków 1977.

${ }^{23}$ S. I. Witkiewicz, Antologia.

${ }^{24}$ M. Średniawa, Realnymi i wirtualnymi tropami Witkacego, w: Witkacy: bliski czy daleki? Materiały międzynarodowej konferencii z okazji 70. rocznicy śmierci Stanisława Ignacego Witkiewicza, Słupsk, 17-19 września 2009, red. J. Degler, Słupsk 2013, s. 568-569.

${ }^{25}$ Zob. http://www.kolekcjapoezji.pl/witryna.html (dostęp: 05.01.2014). Kolejny atut to satynowa zakładka.

${ }^{26}$ Dotąd wydane tomy zob. http://www.kolekcjapoezji.pl/witryna.html (dostęp: 05.01.2014).

${ }^{27}$ S. I. Witkiewicz, Antologia, s. 7.

${ }^{28}$ Mamy tu do czynienia z zagadnieniem nieco podobnym do postępowania Zielonej Sowy wobec Upadków Bunga.

29 "Lepiej jednak skończyć nawet w pięknym szaleństwie niż w szarej, nudnej banalności i marazmie"; Stanisława Ignacego Witkiewicza wiersze i rysunki, s. 146.

${ }^{30}$ S. I. Witkiewicz, Antologia, s. 134-137, 146-147 i 158-159.

${ }^{31}$ Nie uwzględniałam, za katalogiem Biblioteki Narodowej, cytatu w tytule publikacji.

${ }^{32}$ Choć często nie w bezpośrednim sąsiedztwie rysunków, na których zostały umieszczone.

${ }^{33}$ Widać to w zestawieniu z następnym tytułem: książkę Jakimowicz drukowano na papierze rotograwiurowym III kl., gramatura 120.

${ }^{34}$ I. Jakimowicz, Witkacy. Chwistek. Strzemiński. Myśli i obrazy, Warszawa 1978.

${ }^{35}$ Eadem, Witkacy - malarz.

${ }^{36}$ Stanisław Ignacy Witkiewicz. Witkacy 1885-1939. Kolekcja Muzeum Pomorza Środkowego w Słupsku, oprac. A. Krzyżanowska-Hajdukiewicz, Warszawa 1987.

${ }^{37}$ B. Zgodzińska, Próba rekonstrukcji pierwotnej kolorystyki papierowego podłoża portretów Witkacego, w: Witkacy: bliski czy daleki?, s. 397-401, o reprodukcjach barwnych s. 399-400; Radziwilłowie pędzlem i piórkiem Józefa Mehoffera. Wystawa ze zbiorów Muzeum Pomorza Środkowego w Słupsku i Muzeum Mazowieckiego w Płocku, oprac. E. Homa-Rożek i B. Zgodzińska, Człuchów 2003, s. 22

${ }^{38}$ P. Piotrowski, Stanisław Ignacy Witkiewicz, Warszawa 1989.

${ }^{39}$ Portretowana to zapewne Maria Zofia Baworowska; S. I. Witkiewicz, Dzieła zebrane, t. 21: Listy do żony (1933-1935), przygotowała do druku A. Micińska, oprac. i przypisami opatrzył J. Degler, Warszawa 2010, s. 41 i 401

${ }^{40}$ Stanisław Ignacy Witkiewicz (1885-1939). Katalog dzieł malarskich, oprac. I. Jakimowicz przy współpracy A. Żakiewicz, Warszawa 1990.

${ }^{41}$ Zob. http://www.agraart.pl/cgi-bin/autor.cgi?act=1\&nr=311 (dostęp: 27.05.2014).

${ }^{42}$ A. Micińska, Witkacy. Stanisław Ignacy Witkiewicz. Zycie i twórczość, Warszawa 1990

${ }^{43}$ B. Zgodzińska-Wojciechowska, A. Żakiewicz, Witkacy. Kolekcja dzieł Stanisława Ignacego Witkiewicza w Muzeum Pomorza Środkowego w Słupsku, Warszawa 1996.

${ }^{44}$ Stanisław Ignacy Witkiewicz - Witkacy. 1885-1939, [b. red.], Poznań 2007. Zaletą tej publikacji są zaskakujące komentarze w opisach do obrazów: według anonimowego inter- pretatora św. Antoni na Kuszeniu II z lat 1921-1922 przybrał postać modlącej się dziewczyny, ubranej w żółtą suknię.

${ }^{45}$ Dziwność istnienia. The Strangeness of Existence. Witkacy, B. Zgodzińska, Marki 2006.

${ }^{46}$ B. Zgodzińska, Witkacy w Stupsku. Firma Portretowa "S. I. Witkiewicz" / Witkacy in Stupsk. The "S. I. Witkiewicz” Portrait Painting Firm, tłum. na angielski B. Brodniewicz, Słupsk 2010.

${ }^{47}$ A. Żakiewicz, Witkacy, Olszanica 2012.

${ }^{48}$ Eadem, Witkacy, Wrocław 2004 („W Zwierciadle Sztuki”); eadem, Witkacy (1885-1939), Warszawa 2006 („Ludzie, czasy, dzieła”). 